\title{
Articles
}

\section{Learning Cell Biology as a Team: A Project-Based Approach to Upper-Division Cell Biology}

\author{
Robin Wright ${ }^{*} \ddagger$ and James Boggs ${ }^{\dagger}$
}

*Department of Zoology and ${ }^{\dagger}$ Department of Communications, University of Washington, Seattle, Washington 98195

Submitted March 29, 2002; Revised July 22, 2002; Accepted July 29, 2002

Monitoring Editor: Elizabeth Vallen

To help students develop successful strategies for learning how to learn and communicate complex information in cell biology, we developed a quarter-long cell biology class based on team projects. Each team researches a particular human disease and presents information about the cellular structure or process affected by the disease, the cellular and molecular biology of the disease, and recent research focused on understanding the cellular mechanisms of the disease process. To support effective teamwork and to help students develop collaboration skills useful for their future careers, we provide training in working in small groups. A final poster presentation, held in a public forum, summarizes what students have learned throughout the quarter. Although student satisfaction with the course is similar to that of standard lecture-based classes, a project-based class offers unique benefits to both the student and the instructor.

Keywords: collaborative learning, upper-division cell biology, team building, assessment, project-based learning, human diseases.

\section{INTRODUCTION}

A major challenge in teaching and learning cell biology is the enormous and continually expanding information base in our discipline. In just the year 2001, the National Libraries of Medicine PubMed database listed 136,775 articles with the word cell in their title or abstract. Nearly 6,300 articles published in 2001 contain the phrase "cell biology" or "cellular biology." This increasing wealth of information makes designing a series of courses that "covers" all aspects of cell biology virtually impossible during the $4-5$ yr that an undergraduate student spends at the university. The challenge is even more acute for universities such as the University of Washington, where most students take a single 10-week class in cell biology without any required laboratory section.

Students at the University of Washington can obtain Bachelor of Science degrees in cellular and molecular biology, ecology, evolution, and conservation biology, botany, zoology, neurobiology, microbiology, or biochemistry. Several cell biology courses are offered, including an introductory class (Introduction to Molecular Cell Biology, Biology 355) and two

DOI: $10.1187 /$ cbe.02-03-0006

‡Corresponding author. E-mail address: wrightr@u.washington. edu. upper-division courses (Cell Biology, Biology 401; Molecular and Cellular Biology of Plants, Botany 428). None of these classes is required for completion of any of the biological sciences majors, but the 400-level cell biology courses are electives for all the degree programs. In addition, many cellular and molecular biology majors choose to take Biology 401 and a two-quarter biochemistry series in lieu of three quarters of biochemistry. (A significant overlap exists between the content of Biology 401 and the third quarter of a yearlong biochemistry series, Biochemistry 442.) About $75 \%$ of the molecular and cellular biology majors take Biology 401 during their undergraduate education at the University of Washington. Students entering Biology 401 have taken 1 yr of general biology, which includes approximately 15 weeks of instruction in cell biology, genetics, and physiology. Students also must have completed at least two quarters of organic chemistry and either introductory cell biology or an upperdivision class in genetics, physiology, or biochemistry. Thus, students enter Biology 401 with considerable experience in traditional, content-driven courses that cover material relevant to cell biology.

Biology 401 is a 5-credit course, representing approximately one-third of an average student's 15-credit-hour-per-quarter course load. The traditional, lecture-based course meets four times each week in three 50-min lectures and one 2-h, teaching 
assistant (TA)-led discussion section during which students analyze portions of research papers (see http://www. washington.edu/students/icd/S/biology/401mbhille.html). Assessment of student performance is based on writing assignments, exams, and discussion-section participation. This traditional course design emphasizes learning key areas of cell biology content, as well as experimental methodology and analysis. Student evaluations at the end of the class indicate that they are well satisfied with the course (see http:// www.google.com/u/washington ? $\mathrm{q}=$ biol $+401 \& \mathrm{hq}=$ inurl $\% 3$ Awww.washington.edu $\% 2$ Fcec).

After several years of teaching a traditional version of the upper-division cell biology course, I became concerned that students were not learning how to learn cell biology. My emphasis on content encouraged them to learn a lot of facts and figures but did not foster a true mastery of the skills that would be important for life after college, much less for graduate school or for professional careers in teaching or biomedical fields. As a result, I designed a new course that replaced essentially all faculty-delivered lectures with student-led team projects on the cellular and molecular biology of specific human diseases. This course redesign has proven to be successful in helping students learn how to navigate the complexity and volume of knowledge in cell biology, as well as to gain insight and appreciation for cell biology research. In addition, because I have much more substantive interactions with my students, the course has renewed my own delight in and commitment to teaching.

\section{LOGISTICS OF THE PROJECT-BASED CELL BIOLOGY COURSE}

\section{General Course Format}

As shown in the syllabus (see Appendix A), the revised class meets three times per week for $2 \mathrm{~h}$. The 2 -h class period is important for providing a sufficiently large block of time for students to make progress on their projects and helps in scheduling team presentations. After experimenting with other daily schedules, I determined that holding class meetings on three consecutive days (e.g., Tuesdays, Wednesdays, and Thursdays) is ideal. This schedule usually eliminates missed class periods because of holidays, and the clustering helps students schedule their work hours and other commitments. This schedule also provides research-active instructors with larger blocks of time to focus on their own research.

The class period is used for occasional lectures, classwide discussions, team meetings, team project presentations, and evaluation reviews. The occasional lectures are given as the need arises to share information with the entire class. For example, I usually give a 20-min sample talk on a novel disease to serve as an example for the second presentation. In addition, I often give an informal lecture on broadly relevant research methods such as immunoblotting and cloning techniques. We also discuss effective writing strategies, slide design, and ways to make an effective poster, using examples from my lab and from previous classes. However, on most days no formal presentation is scheduled. Instead, students are allowed to leave the classroom as necessary to work on computers or in the library. The instructor and a graduate TA are available in the classroom to discuss any issue related to content, experiments, presentation skills, or writing. The in- structor and the TA also frequently go to the nearby computer facility to discuss the project as students work. Project presentations occur during the $2 \mathrm{nd}, 5 \mathrm{th}, 9$ th, and 10 th weeks of class.

Students are required to purchase an appropriate cell biology textbook, such as Molecular Biology of the Cell (Alberts et al., 2002). The class is also given a list of the key cell biology research and review journals that are likely to be most useful in this class. Each team, in consultation with the instructor, identifies and assigns to the rest of the class appropriate textbook readings concerning their topic. For the second and third presentations, students are given instructor-chosen review articles and primary research articles as foundations on which to base their research and presentations. Students obtain from the library and the Internet additional information that is necessary to complete their projects. In early classes, a course web site was maintained that featured instructorchosen information resources. However, this practice was discontinued because most of our current students are extremely skillful in doing Internet searches and did not find the class web site particularly useful. In addition, this resource did not promote the student's responsibility for and skill in obtaining and evaluating resources. Thus, instead of providing our own lists of relevant resources, we devote considerable class time to discussion of information literacy issues, including how to evaluate a potential source's reliability, and students are expected to find additional information on their own.

\section{Projects}

Four to five students work together as a team to research, prepare, and present both oral and written reports concerning the cell biology of a particular human disease. Depending on student input, the teams either focus on the same disease throughout the quarter or switch midway through the quarter. Student preferences are usually about equal on the matter of maintaining versus switching topics, and they realize the breadth versus depth trade-offs inherent in this decision.

The overall course is divided into four segments. The first three are punctuated with a paper and an oral presentation: the first segment focuses on the organelle or cellular process affected by the disease; the second segment deals with the cellular and molecular biology of the disease; the third segment focuses on recent research, with topics ranging from disease pathology to development of therapies to use of model organisms. The final segment is a poster presentation that allows students to bring all the information together into a coherent whole and serves as an impressively visible metric of how far they have come in their understanding and mastery of complicated information. The logic of this progression from simple to complex mirrors how most researchers, as experienced learners, approach new material. When confronted with a need to learn something completely new, we often begin with textbooks, move into review articles, and finally dig into the primary research.

\section{Team Evaluation}

At the beginning of each project segment, students receive an evaluation checklist that also serves as the grading standard for that project (see Appendixes B-D and Table 1). Separate grades are given for the oral presentation and the paper. Evaluation of the work is explained in detail in a conference with 
Table 1. Evaluation criteria and checklist for poster

The Cell Biology of Human Disease Poster Session will be held in the commons of Mary Gates Hall from 8:30 to 10:30 on Wednesday, August 16. You will need to arrive by about 8:00 in order to set your poster up. We'll provide tables and tape. If you have any special needs, please let us know by Monday, August 14th. Each team member will take turns standing by the poster and asking questions while the other team members view the other posters and make notes on the worksheet. We'll change about every 15 minutes.

\begin{tabular}{|c|c|c|c|c|c|c|}
\hline Part of presentation & Criteria & Excellent & Very good & Good & Average & Poor \\
\hline \multicolumn{7}{|l|}{ Poster Presentations } \\
\hline \multirow[t]{3}{*}{ Title } & \multicolumn{6}{|l|}{ Give take-home message in title. } \\
\hline & $\begin{array}{l}\text { Is title legible from a distance of at least } \\
6 \text { feet? }\end{array}$ & & & & & \\
\hline & Does title include authors' names? & & & & & \\
\hline \multirow[t]{6}{*}{ Affected Organelle } & \multicolumn{6}{|c|}{ Summarize information about the structure \& function of the affected organelle. } \\
\hline & $\begin{array}{l}\text { Describe the general features of the } \\
\text { organelle. Include a picture or diagram. }\end{array}$ & & & & & \\
\hline & $\begin{array}{l}\text { Describe where the organelle is found } \\
\text { within the cell. Picture may be useful. }\end{array}$ & & & & & \\
\hline & $\begin{array}{l}\text { What are the basic functions that this } \\
\text { organelle carries out? Why do cells } \\
\text { need this organelle? Can cells live } \\
\text { without this organelle? What about } \\
\text { multicellular organisms such as } \\
\text { humans? }\end{array}$ & & & & & \\
\hline & $\begin{array}{l}\text { What other organelles contribute } \\
\text { to the function of this organelle? } \\
\text { How does what you have learned } \\
\text { from OTHER projects in the class } \\
\text { affect your understanding of this } \\
\text { organelle? }\end{array}$ & & & & & \\
\hline & $\begin{array}{l}\text { What kinds of problems do defects in } \\
\text { this organelle cause the cell? } \\
\text { the organism? }\end{array}$ & & & & & \\
\hline \multirow[t]{4}{*}{ Disease } & \multicolumn{6}{|c|}{ Give history, symptoms, treatment of disease. } \\
\hline & Overview of disease. & & & & & \\
\hline & $\begin{array}{l}\text { How does the defect in the gene } \\
\text { that causes this disease alter } \\
\text { the function of the organelle it } \\
\text { affects? }\end{array}$ & & & & & \\
\hline & $\begin{array}{l}\text { Are there other related diseases? } \\
\text { Do they all affect this organelle? }\end{array}$ & & & & & \\
\hline \multirow[t]{5}{*}{ Current Research Results } & \multicolumn{6}{|l|}{ Summarize research from paper you read. } \\
\hline & $\begin{array}{l}\text { What was the question that the } \\
\text { research addressed? }\end{array}$ & & & & & \\
\hline & What was the key experiment? & & & & & \\
\hline & What were the major conclusions? & & & & & \\
\hline & $\begin{array}{l}\text { What future directions does this } \\
\text { research lead to? }\end{array}$ & & & & & \\
\hline
\end{tabular}


Table 1. (Continued)

Part of presentation
\begin{tabular}{|l|l|l|l|l|l|}
\hline Esthetics & \multicolumn{1}{c}{ Criteria } & \multicolumn{1}{c}{ Excellent Very good Good Average Poor } \\
\hline & $\begin{array}{l}\text { Was the poster well organized, easy to } \\
\text { read, novel, innovative? }\end{array}$ & & & \\
\hline & $\begin{array}{l}\text { Did anything stand out above the } \\
\text { usual? }\end{array}$ & & & & \\
\hline
\end{tabular}

the team, during which the focus is on what needs to be done to improve the quality of the presentation and paper. During this conference, we also ask questions about how the team is functioning and make suggestions for solving perceived problems with the process. After receiving this feedback (see Appendix A, Section IX, for an example) and that of the rest of the class, teams are usually allowed to rewrite their paper for a new grade.

\section{Individual Evaluation}

Full credit is earned by all team members who adequately contribute to the team project. The paper contains information about each student's individual contributions, including which student was the primary author of each section. In addition, the team maintains a project log that details each team meeting, who was in attendance, and what was accomplished (Table 2). Finally, each team member completes a confidential evaluation of the contributions of all other team members (Table 3). This information is typed up by the instructor to provide individual feedback (see Appendix A, Section X, for examples). By examining individual evaluations, the project $\log$, the paper, and the individual portion of the presentation, the instructor can accurately evaluate whether each team member deserves full participation credit.

Initially, I was concerned about achieving fairness and accuracy in assigning appropriate grades to individuals that reflected both the quality of the group's work and an individual's contribution to that work. However, this system of checks and balances, together with the detailed conference with the team after each class segment, enables a substantive evaluation of student performance that is of potentially higher quality than that possible with traditional written exams. For example, the written documentation about the team process (log, individual evaluations, etc.) flags problems with equality of effort. These problems are discussed in the team conference, and members who did not contribute equally are given a decreased portion of the points earned. For instance, during the conference I may suggest that a particular individual appears to have contributed only $80 \%$ as much effort as that of the other team members. Often, the individual and his or her teammates admit the accuracy of the evaluation, and I assign the individual $80 \%$ of the total points earned by the team. Alternatively, the team members may explain the individual's contributions more accurately and that person earns full credit. Thus far, none of the end-of-quarter evaluations have revealed a concern by students that someone received a grade that he or she did not earn, which affirms that my assessment of an individual's grade is perceived to be fair and accurate.

\section{Feedback}

In the week following a presentation, the instructor meets with each team to review the grading, highlight the positive aspects of the presentation and paper, and point out areas for improvement. Each student receives a written synopsis of this critique, together with a typewritten summary of colleagues' evaluations of their contributions (see Appendix A).

\section{Broadening of Learning and Individual Accountability}

The philosophy of this class emphasizes group responsibility in contrast to that of the individual. Because the nature of modern biology also emphasizes group responsibility, as evidenced by the primacy of multiauthored papers, this emphasis is a valid representation of the current status of the cell biology discipline. However, as a way to encourage and evaluate each student's individual mastery of his or her topic as well as the topics of the other teams, one or two take-home exams or individual projects are assigned during the quarter. These exams or projects provide opportunities to promote greater breadth of learning and emphasize the importance of learning from one another. A sample assignment is to prepare a paper that compares and contrasts the molecular mechanisms of each disease presented in class.

\section{Class Size}

The size of the class is limited by the number of student presentations that can be effectively given within two class periods. The second and third presentations (cellular and molecular biology of the disease and recent research) require 30-min time slots: $20 \mathrm{~min}$ for the talk, 5-8 min for questions, and a few minutes to change to the next team. Consequently, a single class section that meets in 2-h blocks can include as many as 40 students (eight teams of 5 students). A class with more than 40 students would need to be broken into multiple sections, each with 40 or fewer students. The major factor determining the smallest class size for a team-based approach is the need to have a sufficient number of projects so that students are exposed to a breadth and variety of cell biological information. I estimate that a minimum of six projects is required to meet this breadth goal. Thus, the smallest class size that would function well in this team-based framework would be 18 (six teams of 3 students). In my experience, smaller groups do not function as effectively in building teamwork skills. However, if the teamwork aspect of the course is not a priority, the class could contain as few as 6 students, each working independently. 
Table 2. Example of a team project $\log ^{a}$

7/19, 10:40-1:00 The group met in the computer lab after the presentations to assign the members parts to revise the organelle paper. Rob and Jim worked on addressing the comments on the latter half of the paper while Pearl and Katy worked on the first half. Sally had begun to design the template for the next presentation. Before we left, the group agreed on finishing the assigned revisions and will send them to Sally for final editing over the weekend.

7/23, 5:00-6:00 Katy and Sally met in Hitchcock Hall to work on the last of the editing for the final version of the paper.

7/24, 8:30-10:40 After hearing the short session on several biology research methods from Robin, the group decided to present the immunoprecipitation and immunofluorescence data from the research paper. The group went to the computer lab to do additional research on these methods. Pearl talked to Robin about the experiments presented in the paper.

7/25, 8:30-10:40 The group shared their new information with each other. After the guild meeting, the group filled out the research worksheets together and assigned each member to look into new concepts, methods, and vocabulary of the journal article to share and inform the rest of the members by next session.

7/26, 8:30-10:40 Sally came with an outline of the results of the journal article. The group composed an outline for the slides and presentation. The group deciphered the results by talking to each other and to Robin and the TA. Katy agreed to e-mail all of the members a copy of the outline.

7/31, 8:30-10:40 After Robin showed examples of posters from previous years, the group made up an agenda for the presentation and discussed more about the content of the slides. The group agreed to meet in the computer room for the next session.

8/1, 8:30-10:40 Jim and Katy continued to work on the structure of the slides as the rest of the group worked on the poster. Pearl and Rob looked for images from the Web for the poster.

8/2, 8:30-1:00 The group met in the computer lab again to work on the slides. Jim came with images and a diagram for the slides. Pearl gave her ideas and opinions on the poster to Sally, who had most of the poster finished. Sally left a little after noon for her class and the group decided to meet on Friday (8/3) at 10 am in the Odegaard Library. Jim said he might not show up for that session. Robin will be gone until Tuesday for a family emergency. The group agrees to work with him via e-mail to complete the project.

8/3, 10:00-12:30 Pearl, Sally, and Katy met in the Odegaard Library to tweak the poster and slides, as well as prepare for the actual presentation. Jim came in at 11:30 to work on his part of the presentation. Jim agreed to type the project log and to submit the poster file to the print shop so it will be printed by Monday. The group discussed plans for revision of the previous paper.

${ }^{a}$ Student names have been changed to protect privacy.

Table 3. Team members' feedback forms

\section{YOUR NAME:}

Team:

\begin{tabular}{|c|c|c|c|c|c|}
\hline Team Member's Name: & Excellent & Very good & Good & Poor & Not at all \\
\hline $\begin{array}{l}\text { How well did this member of your team listen and take into account the suggestions } \\
\text { of others? }\end{array}$ & & & & & \\
\hline How fully did this team member participate in planning and carrying out the projects? & & & & & \\
\hline How valuable were this team member's contributions to the success of the projects? & & & & & \\
\hline
\end{tabular}

Assume that the amount of time you spent on the project is $100 \%$. What proportion of effort did this individual put into the poster presentation relative to the amount of effort you put in?

If this person worked HARDER than you did, he or she will have a score that is greater than 100. For example, if he or she worked twice as hard as you, he or she will have a score of 200 .

If this person did NOT work as hard as you did, he or she will have a score that is less than 100 . For example, if he or she worked $1 / 2$ as hard as you, he or she will have a score of 50 .

Do you have any helpful suggestions, rants, or raves that you want me to pass on to this person? (I will type them out so your handwriting won't be recognized.) 


\section{SELECTION OF DISEASES FOR THE PROJECT-BASED CELL BIOLOGY COURSE}

Two major criteria drive the choice of a particular disease for inclusion as a topic for learning cell biology. First, a recent research paper concerning a cell biologically relevant aspect of the disease must be available. Consequently, selection of the specific diseases to use in a particular quarter begins with searches for one to three recent research papers that use a variety of experimental approaches relevant to cell biology. The second criterion for choosing a particular disease is to provide a balance of topics so that the class will be introduced to a broad spectrum of cell biological subjects. For example, I typically try to select a spectrum of diseases that, when considered together, represent most major organelles within eukaryotic cells.

Although partial understanding of the underlying pathology of most of the selected diseases is not essential, it is helpful. A balance of "we don't yet know" opportunities along with diseases whose molecular bases have been well deciphered seems to work best for the class as a whole. Appendix E lists the diseases that were chosen during the past $2 \mathrm{yr}$, along with references to assigned review and research papers.

\section{PROMOTION OF EFFECTIVE TEAMWORK}

\section{The Challenge of Change}

Probably the most frightening aspect of switching from lecture-based teaching to a project-based class is the challenge of making sure that teams work together effectively. Devoting most class periods to teamwork helps, because scheduling a time at which all team members can meet outside scheduled class periods is frequently impossible. However, simply having time to work together does not ensure that individuals within a team can actually work together effectively. To this end, the initial organizing of teams on the first day of class represents a critical nexus on which the success of the entire class rests. We devote most of the first 2-h class period to dividing students into teams and discussing how to work well in groups. Use of a "guild system," as developed by Dr. James Boggs, has proven extremely effective for promoting effective teamwork and setting the stage for students to learn how to interact cooperatively. Additional suggestions for effective team building in undergraduate biology classes are given by Allen and Duch (1998).

\section{The Guild Concept}

Before establishing teams, we divide the class into groups, or "guilds," on the basis of each student's perception of his or her individual strengths. Four guilds seem to work well in building teams: 1) an administrator guild that organizes team efforts, 2) an artist guild that helps the team think creatively, 3) a communicator guild that facilitates interpersonal interactions among team members, and 4) an expeditor guild that steps in and performs functions as needed. After guilds are established, project teams are formed with individuals who represent each guild. Typically, each team includes only one individual from the administrative guild, but it can have multiple representatives from any of the other guilds.

\section{The First Day of Class}

After reviewing the syllabus, grading criteria, adds and drops, and other straightforward logistical issues related to the class, we begin by having each person tell us a positive adjective that describes one of his or her major strengths or "gifts." One way to help students think about this adjective is to ask them to tell us how their friends would describe them. After a few minutes, the instructor asks each student to share this adjective or phrase with the rest of the class.

One by one, each student gives a descriptive adjective, which the instructor writes on the board without comment so that the adjectives are grouped into appropriate sets. For example, "organized" would be written on an unlabeled section of the board reserved for people who will become members of the administrator guild. "Creative" would be written on the area of the board reserved for the artist guild. "Flexible" would be written on an area of the board reserved for the expeditor guild. "Friendly" would be written on an area of the board reserved for the communicator guild. Characteristics appropriate for each guild are listed in Table 4 . The instructor keeps tabs on only the administrator guild types and works to ensure that the number of administrators equals the eventual number of teams. If enough administrators have been found, the instructor asks the student to provide a second adjective and writes that word instead of the one that was first offered. Because everyone has multiple strengths, this shuffling of individuals into other groups is not viewed negatively, especially because the purpose of the grouping has not yet been revealed to the students.

The students move so that they are sitting in groups as listed on the board and work together to select a guild name and motto. The students then discuss the positive contributions that their strengths bring to effective teamwork. Then, so that each individual can recognize the ways in which his or her strengths, if taken too far or used inappropriately, can cause problems for teams, the groups are asked to discuss the negative aspects of the guild. For instance, if someone in the administrator guild is "determined," he or she may drive the others too hard and cause discord in the group.

After the guilds explore their strengths and weaknesses, the whole class reconvenes to discuss the positive and negative contributions of their guild members to effective teamwork. The class examines each guild's perspectives of its roles in team efforts and spends some time talking about the advantages and challenges of working together. Finally, teams are formed with one individual from the administrator guild and the remaining members from each of the other guilds. On the basis of experimenting for $4 \mathrm{yr}$ with larger and smaller team sizes, I settled on having teams with four or five members as being ideal for spreading the work out equally and for buffering personality conflicts.

After introducing themselves to one another and spending time obtaining contact information, the teams are immediately set to work. They select a number from a hat and receive a corresponding folder that contains a story about an individual with the disease that they will be researching for the quarter. References to the identity of the disease have been removed from the story, but students are told that the disease is caused by a single genetic defect. They are asked to work together to devise a hypothesis to explain what cellular structure or process is altered as a result of the mutation. 
Table 4. Sample personal strength descriptors grouped into guilds

\begin{tabular}{llll}
\hline Administrator guild & Artist guild & Communicator guild & Expeditor guild \\
\hline Organized & Creative & Friendly & Detail oriented \\
Task oriented & Visual & Positive & Meticulous \\
Disciplined & Artistic & A people person & Good record keeper \\
Timely & Emotional & Sympathetic & Flexible \\
Conscientious & Original & Kind & Responsible \\
Efficient & Innovative & Caring & Have special skill in some \\
Practical & Designer & Sociable & area (writing, computers, \\
Leader & Theatrical & Friendly & etc.) \\
Determined & & Understanding & Jack of all trades \\
Focused & & Arbitrator & Reliable \\
Efficient & & Mediator & Hard working \\
Methodical & & Diplomat & Resourceful \\
& & Motivator & Versatile \\
\hline
\end{tabular}

\section{The Structuring of Team Efforts}

The initial three to four class periods are structured so that the teams must work together to complete specific tasks, such as learning how to do BLAST (Basic Local Alignment Search Tool) searches to identify their gene of interest. As the quarter progresses, direction from the instructor is gradually reduced to the point that the team does all planning for upcoming events. Appendix F provides an example of a structured activity that helps the teams learn how to plan and organize their projects.

\section{Guild Meetings}

Teams work together for several class periods, then a short guild meeting is called in which guild members can discuss what is working well in their groups, what problems are arising, and which ways they can effect positive change in their team. Such meetings are more important in the early weeks of the class (i.e., just before and after the first presentation) than later in the class. Teams seem to rapidly settle into a clear understanding and appreciation of each person's role and move forward with the tasks at hand. In addition, students learn to take on multiple roles as their talents and interests allow. Thus, the most important gains provided by the guild exercise may be in forming more "balanced" teams and in helping students realize, appreciate, and respect their teammates' abilities and contributions.

\section{VALUE OF THE PROJECT-BASED CELL BIOLOGY CLASS}

More than $60 \%$ of all students who enter the University of Washington think that what they will learn in their major will be "extremely important" for their success after leaving college. ${ }^{1}$ However, when our students are surveyed $5-10 \mathrm{yr}$ after graduation, only slightly more than $25 \%$ of the students

${ }^{1}$ D.E. McGhee, University of Washington Entering Student Survey 2001, Item 16, http://www.washington.edu/oea/ 0203freq.pdf, last accessed March 17, 2002. find that what they learned in their major is "essential" for their current primary activity. ${ }^{2}$ In contrast, the perceived importance of skills such as communication, problem solving, leadership, and working together effectively increases. Not surprisingly, students believe that their university training does a good job "teaching them their major" but not as well in helping them gain the skills that they tell us are important for success after college. The unfortunate conclusion is that we are doing a good job teaching our students things that may not matter much in the long run. The desire to make a longterm difference in students' lives and careers was one factor that motivated our developing a project-based cell biology class.

Project-based cell biology moves the students away from a focus on content to a clearly defined focus on communication, leadership, teamwork, and other skills needed for lifelong success, while modeling how scientists in general, and cell biologists in particular, learn new material. Although many students act as if they have been waiting all their lives to be allowed to tackle a problem creatively, others students are less comfortable with such open-ended activities (Hansen and Stephens, 2000). As a consequence, my course evaluation scores remain essentially the same whether I teach a traditional lecture-based cell biology course or a completely project-based course. The student-perceived "effectiveness of the instructor" is usually decreased for the project-based course, probably because I am facilitating their independent learning rather than lecturing.

The most common criticism from students in the projectbased course is that they think they did not learn as much as they would have in a lecture-based class. I believe that part of this dissatisfaction is an illusion; students appear to base their perception of the amount that they learned on the number of pages of lecture notes that they accumulate or the number of chapters that they were assigned to read. Student satisfaction with problem-based cell biology increased when I began handing out all the team articles and project papers and asking students to search for connections between their

${ }^{2}$ D.E. McGhee, Undergraduate Degree Recipients: Five and Ten Years After Graduation, Item 11, http://www.washington. edu/oea/0006t.pdf, last accessed March 17, 2002. 
disease, organelle, process, and so forth, and those presented by the other teams (Appendix $G$ ). The amount of information we were "covering" became obvious as their notebooks filled with the presentation notes and papers from each team, as well as the entire complement of review and research articles for all the class projects.

An initial concern of many students confronting a projectbased course for the first time stems from the requirement that they work in groups. Some students worry that their grades will suffer or that other team members will not work as hard and they will consequently receive a grade that they do not deserve. The underlying concern appears to be one of fairness. The integrated system of checks and balances (project logs, confidential team member evaluation, etc.) helps assure students that grading will be fair and take into account individual contributions. End-of-quarter evaluations confirm that the students perceive the grading to be fair, which indicates that these initial fears were unfounded. To deal with perceptions that an individual effort would be of higher quality than a group effort, I occasionally allow an individual to turn in a paper that represents his or her exclusive effort. With only one exception thus far, individual efforts are of poorer quality and receive lower grades than those of the corresponding team efforts. Once students see this result, they quickly become converts to the team approach.

In assessing course effectiveness, an initial issue is the student composition in the traditional classes versus that in the project-based class. Because the traditional classes are offered during the academic year and the project-based class is offered in the summer, the two types of classes may serve different populations of students. Comparisons of the summer 2000 class (project based) and the autumn 2000 class (traditional) uncovered two interesting differences: on average, students taking the project-based class had less than half as many transfer credits as those taking the traditional class, and the summer class contained four nonmatriculated students. Nonmatriculated students are rarely included in the academic-year Biology 401 classes because of high demand for the class by matriculated students. Despite these differences, both classes appear to include students with similar academic potential. For example, both classes have similar overall grade point averages (3.1 for the summer 2000 class [project based] and 3.2 for the autumn 2000 class). In addition, both classes have similar graduation rates: $83 \%$ of the summer 2000 class (project based) and $85 \%$ of the autumn 2000 class had obtained a biology degree by spring 2002. Most students in both classes are molecular and cellular biology majors.

Direct comparisons of student performance following lecture-based versus project-based courses are difficult or impossible because the two courses have different learning objectives and outcomes. However, one measurement of the effectiveness of project-based learning is evaluation of student performance at the beginning and at the end of the quarter. In the summer 2001 class, the average grade for the first project presentation was a " $\mathrm{B}$ " and the average paper grade was a "D." By the second project, the average presentation grade improved to a solid and impressive "A," a gain that was maintained in the final presentation, which also was "A"-quality work. The average paper grade on the second project improved to a "B+" and was an " $\mathrm{A}$ " for the third project. The rapidly improving and generally high grades in the project-based class demonstrate the ability of students working in teams to meet and often exceed even very high expectations.

Table 5. Comparison of biology grades of students before and after taking upper-division cell biology (Biology 401)

\begin{tabular}{|c|c|c|c|c|}
\hline \multirow[b]{2}{*}{ Discipline } & \multicolumn{2}{|c|}{ Students taking project-based cell biology course ${ }^{a}$} & \multicolumn{2}{|c|}{ Students taking traditional cell biology course } \\
\hline & Average grades $^{c}$ & $\begin{array}{l}\text { No. students/ } \\
\text { no. courses taken }\end{array}$ & Average grades ${ }^{c}$ & $\begin{array}{l}\text { No. students/ } \\
\text { no. courses taken }\end{array}$ \\
\hline \multicolumn{5}{|l|}{ Biochemistry } \\
\hline Before cell biology & $2.84 \pm 0.24$ & $20 / 6$ & $2.79 \pm 0.47$ & $28 / 6$ \\
\hline After cell biology & $3.37 \pm 0.37$ & $53 / 5$ & 3.20 & $14 / 4$ \\
\hline After cell biology & 3.38 & $8 / 4$ & 3.41 & $6 / 4$ \\
\hline \multicolumn{5}{|l|}{ Botany } \\
\hline Before cell biology & 3.60 & $4 / 3$ & 3.56 & $5 / 5$ \\
\hline After cell biology & 3.33 & $4 / 4$ & 2.60 & $7 / 6$ \\
\hline \multicolumn{5}{|l|}{ Genetics } \\
\hline Before cell biology & $2.51 \pm 0.34$ & $35 / 4$ & $3.30 \pm 0.32$ & $30 / 4$ \\
\hline Before cell biology & $3.19 \pm 0.48$ & $35 / 17$ & $3.11 \pm 0.78$ & $33 / 16$ \\
\hline After cell biology & $3.02 \pm 0.74$ & $24 / 15$ & $2.71 \pm 1.02$ & $33 / 13$ \\
\hline
\end{tabular}


Because of the nontraditional focus and format of the project-based cell biology class, one concern is that it may not prepare a student for subsequent traditional biology classes as well as a lecture-based cell biology class does. We do not have access to students' graduate record examinations (GRE) or Medical College Admission Test (MCAT) scores. Consequently, to assess this possibility, we compared the grades of the students taking Biology 401 in summer 2000 (project-based class) with those of the students taking Biology 401 in autumn 2000 (traditional class). The comparison, shown in Table 5, indicates that students taking the project-based class and those taking the traditional class had similar grades in subsequent biology classes. Thus, taking the project-based class did not adversely affect student performance in subsequent classes.

Perhaps as important as the students' improved performance during the quarter and their overall satisfaction with the course (see Appendix $\mathrm{H}$ ) is that teaching a project-based class energizes me as a teacher and as an individual. I have learned new skills and approaches by watching how my students interact with one another. For example, one team struggled with an unusual team member, to the point that I offered them the option of essentially "voting the person off the island." The team refused and, through their gentle but persistent efforts, was able to develop strategies for interacting with the recalcitrant individual, which enabled this person to contribute in substantial and novel ways to the team's efforts. Seeing such dedication in my students inspires me to greater efforts to teach all my classes in a way that is inclusive and more understanding of different learning styles, personalities, perspectives, strengths, and weaknesses.

Some of my students have been incredibly creative in ways that I would never have had the opportunity to see if I had not relinquished "control" of the class. For example, one team got in touch with a local epidermolysis bullosa (EB) support group and became acquainted with a young man who had this disease. They invited this young man to talk to the class about what it was like to live with EB. I have rarely seen a class as engaged, actually riveted, as when this young man talked about the traumas of being ridiculed when he was in elementary and high school for having to sit out of physical education classes or wear shoes several sizes too large. This engagement translates itself into a wonderful and welcome benefit: I have never heard a single student in my class ask, "Do I need to know this?" or "Is this going to be on the exam?" Life is the exam, and my students tell me that their experiences in our project-based class help prepare them for future academic and personal challenges.

\section{REFERENCES}

Alberts, B., Johnson, A., Lewis, J., Raff, M., Roberts, K., and Walter, P. (2002). Molecular Biology of the Cell, New York: Garland, xxxiv, 1463.

Allen, D.E., and Duch, B.J. (1998). Thinking Toward Solutions: Problem-Based Learning Activities for General Biology, Orlando, FL: Harcourt Brace \& Company.

Hansen, E.J., and Stephens, J.A. (2000). The ethics of learner-centered education. Change 32, 40-47.

\section{ONLINE RESOURCES FOR INFORMATION ABOUT HUMAN DISEASES}

Family Village: Excellent collection of links to support groups and foundations for specific diseases. http://www.familyvillage.wisc. edu/index.htmlx

GeneCards: Useful organization of links to information about specific human genes. http://nciarray.nci.nih.gov/cards/

GeneTests.GeneClinics: Resource for disease symptoms and clinical tests; you must complete a lengthy but free registration that is well worth the effort. http://www.geneclinics.org/

OMIM: Online Mendelian Inheritance in Man: Extremely useful, technical summaries of symptoms of, history of, basis of, and research on human genetic diseases. http://www.ncbi.nlm.nih.gov/entrez/ query.fcgi?db=OMIM 


\section{Appendix A \\ Syllabus for Project-Based Cell Biology Class (Summer 2001)}

\section{Class Meetings}

Class meeting

Biology Study Area

II. Instructors
We meet Tuesday, Wednesday, Thursday from 8:30-10:30 in Mary Gates Hall, Room 242

Hitchcock 220-Dave Hurley manages the Biology Study Area (BSA), where you can find Macintosh computers to check your e-mail, to do Web searches, and to write your papers. In addition, the BSA maintains a large collection of textbooks, slides, and videos that may be useful for your project preparation and planning.
Robin Wright

wrightr@u.washington.edu

238 Kincaid Hall

Lab: 206-685-3651
Wendy Rockhill

wrockhil@u.washington.edu

248 or 154 Kincaid Hall

Lab: 206-616-3383

\begin{abstract}
Robin Wright is an associate professor in the Department of Zoology. She has been at the University of Washington for almost 11 years. Her research focuses on understanding how cells alter their structure in response to physiological or environmental changes. Robin graduated from the University of Georgia, with a B.S. in biology, and obtained her Ph.D. in molecular biology from Carnegie-Mellon University, in Pittsburgh, PA. She then did postdoctoral work at the University of California, Berkeley, for 4 years before coming to the University of Washington in September 1990.

Wendy Rockhill is a graduate student in the Department of Zoology. She has been at the University of Washington for 2 years. She has bachelor and master of science degrees from Western Washington University. Her master's thesis involved analysis of vertebrate morphology. Her current research is in the area of cellular and developmental biology. She is studying the migration and physiology of gonadotropin-releasing hormone ( $\mathrm{GnRH})$ neurons as well as their interactions with olfactory and vomeronasal neurons.
\end{abstract}

III. Course Goals

The major goals of this class are to help you learn to:

- Ask questions about cell structure and function

- Understand how these questions can be addressed using modern research tools in cell biology

- Gain insight into the relevance of cell biological research to modern biology and medical science

These goals will be accomplished through completion of four team projects centered on discovering, understanding, and presenting the cellular and molecular biology of a human genetic disease. By the end of the quarter, you will be reading primary research papers and be able to explain the hypothesis, experimental approaches, methodology, controls, results, and shortcomings of the particular research.

\section{Course Philosophy}

General: This course is designed to serve as a transition from lecture-based learning to inquiry-based learning, forming a bridge from your undergraduate classes to postgraduate or professional education. Most, if not all, courses that you have taken so far are designed to provide you with a survey of information about a particular topic. Instead, this course will help you learn to think like a scientist. Consequently, instead of sitting through lectures, you will work in a team to solve problems and give presentations to the rest of the class.

Thus, you will be directly responsible in large part for the success or failure of the course.

This responsibility means that you will probably need to work harder to be successful in this class than you have done in more traditional courses. We estimate that you will need to spend 10-15 hours per week studying outside of class time.

Cooperative learning: Throughout the course, you will be required to work in teams in order to complete several projects or to formulate presentations for class. Much of the lecture time will be spent working in these teams or presenting projects. 
Instructors' responsibility: In this course, our job is to serve as expert learners who can help direct your explorations into the inner secrets of cells. Because the field of cell biology is so immense, we will be there to help keep you grounded and to point out the forest among the trees when you are in danger of getting lost in the details. We will offer suggestions, advice, and exhortation to help you achieve the maximum possible from this course. We will arrange for you to come to our lab or those of colleagues to see the techniques you need to understand for your presentation. We are partners with you in your learning-eager to help you find, evaluate, and use information or other resources that you need.

\section{Logistics}

The class is divided broadly into four major sections, each punctuated by a presentation in which your team shares what it has learned with the rest of the class and prepares a paper describing those results. The sections are:

1. What is the structure and function of the cellular organelle or process in which this gene product works?

2. What is the cellular and molecular biology of the disease caused by defects in this gene product?

3. What experimental approaches are scientists taking to understand, treat, and/or cure this disease?

4. Poster Presentation (summarizes all of the work you did).

In addition, the final week will be spent working on an individual miniproject or take-home exam that you will prepare on your own.

\section{Evaluation \& Grades}

For this class, your grade will reflect the quality of your team's projects (both the in-class presentation and the report), and your contribution to the projects.

Projects: Every project must involve the efforts of every team member. On written reports, each member must contribute a portion of the paper and each member must proofread and edit all of the contributions of the other members. The final report must be signed by each team member to confirm that each person has had input into and approves the final version of the report. In addition, the report will specifically describe each member's contributions. Finally, the report must include a project log that includes the times the team met, who was present, and a brief description of what was accomplished.

We will give a grade for the team report that reflects both the presentation and the written report. A checklist for each project will be provided, so you will know in advance what my expectations are for that project. In addition, each student in the team will secretly evaluate the contributions and participation of the other members of the team.

Thus, your final grade on the project will reflect my evaluation of your performance as a team as well as the evaluation of your individual participation by your peers. You will get plenty of feedback to make sure that you can improve your reports and projects over the course of the quarter. See the end of the syllabus for examples.

\section{Grading Policies}

The specific grading policies will be established in collaboration with the class. One possibility is shown below:

\begin{tabular}{|l|c|c|}
\hline Topic & Presentation & Paper \\
\hline Cellular organelles or process & 100 & 100 \\
\hline Cellular \& molecular biology of disease & 100 & 100 \\
\hline Current research & 100 & 100 \\
\hline Poster Presentation/Summary & 200 & 200 \\
\hline Take-home exam & & 2 \\
\hline
\end{tabular}


There is no curve in this class. Your grade is the grade you earn, regardless of the performance of your classmates. This means that collaborative efforts should pay off for everyone. The following grade scale will be used:

Grading Standards

\begin{tabular}{|l|l|}
\hline Presentation, reports, exams & General standard \\
\hline A & Excellent work, could not have done any better, clearly exceptional \\
\hline B+ & Very good work, but there is room for improvement in one area \\
\hline B & Good work, but there are several areas where significant improvement is possible \\
\hline C+ & Acceptable, average work; nothing out of the ordinary \\
\hline C & Passing work, but a considerable amount of improvement is needed in many areas \\
\hline D & Work not up to minimal expectations, but effort was clearly made \\
\hline Not passing & Work not acceptable; little or no effort is apparent \\
\hline
\end{tabular}




\section{Tentative Schedule of Activities}

\begin{tabular}{|c|c|c|}
\hline Tuesday & Wednesday & Thursday \\
\hline June 19 & June 20 & June 21 \\
\hline $\begin{array}{l}\text { Work on presentation (cell } \\
\text { structure \& function) }\end{array}$ & $\begin{array}{l}\text { Work on presentation (cell structure \& } \\
\text { function) } \\
\text { Turn in plan for disease presentations }\end{array}$ & $\begin{array}{l}\text { Work on presentation (cell structure \& } \\
\text { function) }\end{array}$ \\
\hline $\begin{array}{l}\text { July } 3 \\
\text { Presentations (cell structure \& } \\
\text { function) }\end{array}$ & July 4: HOLIDAY & $\begin{array}{l}\text { July } 5 \\
\text { Lecture: Cell biology of disease } \\
\text { Receive references for review papers; } \\
\text { work on cell biology of disease } \\
\text { presentation }\end{array}$ \\
\hline $\begin{array}{l}\text { July } 10 \\
\text { Work on cell biology of disease } \\
\text { presentation }\end{array}$ & $\begin{array}{l}\text { July } 11 \\
\text { Work on cell biology of disease } \\
\text { presentation } \\
\text { Turn in plan for disease presentations }\end{array}$ & $\begin{array}{l}\text { July } 12 \\
\text { Work on cell biology of disease } \\
\text { presentation }\end{array}$ \\
\hline $\begin{array}{l}\text { July } 17 \\
\text { Work on cell biology of disease } \\
\text { presentation }\end{array}$ & $\begin{array}{l}\text { July } 18 \\
\text { Disease presentations }\end{array}$ & $\begin{array}{l}\text { July } 19 \\
\text { Disease presentations } \\
\text { Receive research paper(s) }\end{array}$ \\
\hline $\begin{array}{l}\text { July } 24 \\
\text { Work on research presentation }\end{array}$ & $\begin{array}{l}\text { July } 25 \\
\text { Work on research presentation }\end{array}$ & $\begin{array}{l}\text { July } 26 \\
\text { Work on research presentation }\end{array}$ \\
\hline $\begin{array}{l}\text { Aug } 15 \\
\text { Finish up poster; make sure it is printed }\end{array}$ & $\begin{array}{l}\text { Aug } 16 \\
\text { Poster Session }\end{array}$ & $\begin{array}{l}\text { Aug } 17 \\
\text { Take-home exam due } \\
\text { Looking back, looking forward }\end{array}$ \\
\hline
\end{tabular}




\section{Sample Feedback for Team Project}

\begin{abstract}
After your presentation and paper have been completed, I will give you the checklist on which I wrote comments during your presentation, together with comments such as those shown below. The checklist will have the number of points your team earned for this project.

Group 3

Presentation Grade: 43

Paper Grade: 38

Members: A., E., M., D.

Disease: Machado Joseph Disease

Protein/gene: Ataxin

Cell biology topic: Ubiquitin-mediated protein degradation

Slides were well designed and attractive. Unique approach ("kiss of death, chamber of doom") makes presentation interesting. You handled the history of discovery of ubiquitin very well. Did a nice job in describing how proteins get ubiquitinated. Your whole team fielded questions well. You needed to include more information on cell cycle (how cyclins work) and on ubiquitin-related diseases; switch slides 6 and 7; heat shock = stress response; slide 11: don't use abbreviation without defining (HPD?); not clear what "highly conserved" means—what 3 changes occur (amino acids, nucleotides, etc.)?

Suggestions: Keep up good work-you knew the material, but needed to fill in a few more details to really do justice to the process. For example, stating the differences between mono- and polyubiquitination earlier would have helped set the stage. The sperm stuff was interesting, but in interest of time, you probably should have talked more about diseases associated in general with ubiquitin. You MUST have references to your photos and diagrams.

On the basis of this paper, I think you know the topic pretty well-but I'm not sure that your audience (your classmates) will really understand it in sufficient detail just on the basis of what you wrote. There are several areas that would benefit from more careful organization (grouping all the enzymology together, for example). Adding more information in several places would also help. In its current form, it is only "C"-quality work. But you can rewrite it for a new grade if you want, after you get feedback from the rest of the class. Note my suggestions onthe paper itself.

Suggestions: Before you begin editing, sit down and read the entire paper together, discussing my recommendations and those you'll get from your classmates. Then make appropriate changes and corrections and additions. You should able to bring this grade up considerably by including more information and doing some considerable editing. If you have any questions, schedule a 30-minute block of time for the whole group to talk to me.
\end{abstract}

\section{Sample Feedback for Individuals}

In addition to the grading for the overall project, each person will receive an evaluation that reflects comments from the team. These comments will be typed by me and are anonymous. The idea is to give you a venue for making helpful comments to your team without hurting feelings or potentially damaging any working relationship. Here is an example of such an evaluation:

\section{Individual 1}

Your team really appreciates the time you spent going to the bookstore to buy the poster board. In addition, they are amazed at the amount of information you know concerning the immune system. It is clear that they value your contributions. However, there is some concern that your family problems forced you to miss several meetings. They understand it was unavoidable, but it did make things difficult for the rest of the team to make up the work. You may want to consider ways to still participate fully in the activities even when you couldn't meet with the team because your daughter was ill.

Full credit for participation

Individual 2

Your group recognizes and appreciates your hard work on the project. They also like your attention to detail. They are really impressed with the number of articles you read and the amount of research you did. However, your impact would be even greater if you were able to work on communicating more effectively with others. The group is a little afraid of you-even though you don't raise your voice, they think that you are angry and upset at them and that you don't appreciate their input. Apparently they feel that your editing job did not retain their contributions. You'll need to work hard on communication skills if the team is going to work well and be able to build upon the strengths of all of the members. Asking for more input and suggestions from the others would a good place to start.

Full credit for participation 


\section{Appendix B}

\section{Evaluation Criteria and Checklist for Presentation and Paper on Cell Structure and Function}

\begin{tabular}{|c|c|c|c|c|c|c|}
\hline \multirow[t]{2}{*}{ Introduction } & \multicolumn{6}{|l|}{ Set stage for talk; give necessary background. } \\
\hline & $\begin{array}{l}\text { In what types of cells would this organelle or process } \\
\text { be present? }\end{array}$ & & & & & \\
\hline \multirow[t]{3}{*}{ Organelle Structure } & \multicolumn{6}{|c|}{$\begin{array}{l}\text { Give enough information so that a student in the class could identify this organelle if shown an } \\
\text { unlabeled diagram or a micrograph (see me if your disease affects a process and not a particular } \\
\text { organelle). }\end{array}$} \\
\hline & $\begin{array}{l}\text { Describe where the organelle is found within the } \\
\text { cell. }\end{array}$ & & & & & \\
\hline & $\begin{array}{l}\text { Are there considerable variations in the number or } \\
\text { the structure of this organelle in different cell types? }\end{array}$ & & & & & \\
\hline \multirow[t]{2}{*}{ Organelle Function } & \multicolumn{6}{|c|}{$\begin{array}{l}\text { Give sufficient information so that the class can appreciate the role of the organelle or the process in } \\
\text { cells. }\end{array}$} \\
\hline & $\begin{array}{l}\text { What are the basic functions that this organelle or } \\
\text { process carries out? }\end{array}$ & & & & & \\
\hline \multirow[t]{2}{*}{ Summary } & \multicolumn{6}{|c|}{ Summarize in a sentence or two the organelle's structure and function. } \\
\hline & Summary & & & & & \\
\hline \multicolumn{7}{|c|}{ Above and Beyond: exceptional presentations } \\
\hline & $\begin{array}{l}\text { Was any novel approach or interesting anecdote } \\
\text { given that would help the audience remember this } \\
\text { subject? }\end{array}$ & & & & & \\
\hline \multirow[t]{3}{*}{ Overheads/Demos, etc. } & \multicolumn{6}{|c|}{ Make sure that the overheads (or slides) are easy to read-don't put too much information on them. } \\
\hline & Were overheads legible and easy to follow? & & & & & \\
\hline & Was the main topic clearly stated on the overhead? & & & & & \\
\hline
\end{tabular}




\begin{tabular}{|c|c|c|c|c|c|c|}
\hline $\begin{array}{l}\text { Part of } \\
\text { report }\end{array}$ & Criteria & Excellent & $\begin{array}{l}\text { Very } \\
\text { good }\end{array}$ & Good & Average & Poor \\
\hline \multicolumn{7}{|c|}{ Reports/Handouts: Cell Structure \& Function } \\
\hline \multirow[t]{12}{*}{ General } & \multicolumn{6}{|l|}{ The paper should be 2 pages, single spaced, with 12-pt font. } \\
\hline & Were the roles of each group member described? & & & & & \\
\hline & Did each group member sign the completed paper? & & & & & \\
\hline & Was the report divided into appropriate sections? & & & & & \\
\hline & Was the report well written? & & & & & \\
\hline & Was the writing clear and to the point? & & & & & \\
\hline & Was jargon avoided? & & & & & \\
\hline & Were topic sentences clearly present in each paragraph? & & & & & \\
\hline & $\begin{array}{l}\text { Did each sentence relate to the prior sentence and } \\
\text { look forward to the next (i.e., was the flow of the } \\
\text { writing appropriate?)? }\end{array}$ & & & & & \\
\hline & Did the report include all references? & & & & & \\
\hline & $\begin{array}{l}\text { Was the discussion log properly maintained? } \\
\text { (Reports without a log will not be graded.) }\end{array}$ & & & & & \\
\hline & $\begin{array}{l}\text { Did each member of the group turn in evaluations } \\
\text { of group participation? (Grades will not be given } \\
\text { until these evaluations are received.) }\end{array}$ & & & & & \\
\hline $\begin{array}{l}\text { Above \& } \\
\text { Beyond }\end{array}$ & \multicolumn{6}{|l|}{ Did anything make this report stand out from others? } \\
\hline & Describe below and rate to right: & & & & & \\
\hline
\end{tabular}


Cell Structure/Function Presentation Checklist

Presentation and Papers on Tuesday, July 3, 2001, 8:30-10:40

\begin{tabular}{|c|c|c|c|}
\hline & Question & Answer & Check \\
\hline \multirow{6}{*}{ 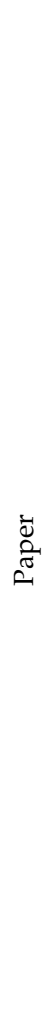 } & When is it due? & $\begin{array}{l}\text { The completed paper is due at the beginning of class. I need BOTH a } \\
\text { hard copy and a floppy (or CD or Zip). }\end{array}$ & \\
\hline & How long can it be? & $\begin{array}{l}\text { Paper should be ABOUT } 2 \text { pages long, single spaced, } 12 \text {-point font, } 1 \\
\text { inch margins. It CAN be longer if necessary-I will read everything } \\
\text { you turn in and count it for your grade. The references and any figures } \\
\text { do not count in the page total. }\end{array}$ & \\
\hline & What is the format? & $\begin{array}{l}\text { The paper should be divided into clearly marked sections, corre- } \\
\text { sponding to the evaluation checklist and to the parts of your talk. } \\
\text { You can modify the checklist to reflect your particular organization } \\
\text { or topics. }\end{array}$ & \\
\hline & $\begin{array}{l}\text { How do I indicate who wrote } \\
\text { which parts? }\end{array}$ & $\begin{array}{l}\text { The paper must include information about who wrote which } \\
\text { sections. You can put the name of the author in parentheses } \\
\text { after the heading. }\end{array}$ & \\
\hline & What about references? & $\begin{array}{l}\text { ALL references must be included, including web-based references. } \\
\text { You should have MORE than JUST text or web references. I estimate } \\
\text { that you should have about } 10 \text { references. Web references in your } \\
\text { paper should have the title of the site, the URL, and the date you } \\
\text { referenced it. } \\
\text { Example: } \\
\text { Mitochondria: architecture dictates function, http://cellbio.utmb. } \\
\text { edu/cellbio/mitoch1.htm, June } 27,2001\end{array}$ & \\
\hline & $\begin{array}{l}\text { How do we document that the } \\
\text { paper represents joint work? }\end{array}$ & $\begin{array}{l}\text { The paper must be signed by all members of the group, stating "We } \\
\text { have read the entire paper and had an opportunity to make editing } \\
\text { suggestions for all parts." }\end{array}$ & \\
\hline 党 & $\begin{array}{l}\text { When are my team member } \\
\text { evaluations due? }\end{array}$ & $\begin{array}{l}\text { You MUST TURN IN your team member evaluations together with } \\
\text { your paper at the beginning of class on July } 3 \text {. If these evals are not } \\
\text { included, your team paper will lose } 5 \text { points for each day any evalu- } \\
\text { ation is missing. }\end{array}$ & \\
\hline \multirow{4}{*}{ 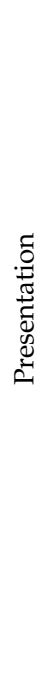 } & $\begin{array}{l}\text { How long do we have for our } \\
\text { presentation? }\end{array}$ & $\begin{array}{l}10 \text { minutes. You will have a warning at } 8 \text { minutes, then have } 2 \text { minutes } \\
\text { to finish up. After } 10 \text { minutes, you will have to stop talking. After the } \\
\text { talk, you will have } 5 \text { minutes for questions. }\end{array}$ & \\
\hline & $\begin{array}{l}\text { How can I get overheads made for } \\
\text { my presentation? }\end{array}$ & $\begin{array}{l}\text { If you need us to make overheads for you, you must bring the origi- } \\
\text { nals BY 5:00 on MONDAY, July 2, 2001. Bring them to Wendy Rockhill } \\
\text { in } 248 \text { Kincaid Hall (616-3383). If you need COLOR overheads, you } \\
\text { must bring the file on a disk. I will bring pens if you need to use them } \\
\text { to write on the overhead. }\end{array}$ & \\
\hline & $\begin{array}{l}\text { How can I have my handouts } \\
\text { copied? }\end{array}$ & $\begin{array}{l}\text { You can make } 35 \text { copies of your handouts to bring with you on Tues- } \\
\text { day. Alternately, we will make copies for you IF YOU BRING THE } \\
\text { ORIGINALS BY 5:00 on MONDAY, July 2, 2001, to Wendy Rockhill } \\
\text { in } 248 \text { Kincaid Hall (616-3383). }\end{array}$ & \\
\hline & $\begin{array}{l}\text { What are we doing about PowerPoint } \\
\text { presentations? }\end{array}$ & $\begin{array}{l}\text { You are safest to stick with fonts such as Times, Arial (Geneva), or } \\
\text { Symbol. If you use an unusual font, please embed the font in your } \\
\text { presentation. You can do this by using the "Save as" function and } \\
\text { checking "Embed font." Getting to the "Embed font" command varies } \\
\text { depending on the version of PowerPoint you are using. }\end{array}$ & \\
\hline
\end{tabular}




\begin{tabular}{|c|c|c|c|}
\hline & Question & Answer & Check \\
\hline \multirow[t]{2}{*}{ 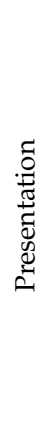 } & & $\begin{array}{l}\text { If you are using PowerPoint, you must bring your presentation by } \\
\text { 5:00, MONDAY, July 2, to Robin Wright in } 238 \text { Kincaid Hall (685- } \\
\text { 3651). You can bring it on a floppy, CD, or Zip disk. NOTE: For Mac } \\
\text { users, please use a PC-formatted floppy or Zip. You can also ftp it, if } \\
\text { you know the ftp address you need to access, but again, you have to } \\
\text { come to my office so we can get it onto my computer ahead of time } \\
\text { and make sure it is functioning. } \\
\text { To judge length of talk, estimate about } 10 \text { slides for a 10-minute talk. }\end{array}$ & \\
\hline & How can I practice my talk? & $\begin{array}{l}\text { Kincaid Hall room } 114 \text { has been reserved for all day on Monday, July } \\
2 \text { (about 8:00 until 5:00). To use the room, come see Robin in } 238 \\
\text { Kincaid. She will have a data projector and computer that you can } \\
\text { use for practice. }\end{array}$ & \\
\hline \multirow{3}{*}{ 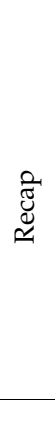 } & Monday & $\begin{array}{l}\text { Get your PowerPoint presentation to Robin so she can load on her } \\
\text { computer. } \\
\text { Bring your handouts to Wendy so she can make copies for you. } \\
\text { Bring originals to Wendy to make overhead transparencies. } \\
\text { Double-check with Wendy or Robin to make sure you have } \\
\text { everything you need for your presentation. }\end{array}$ & \\
\hline & Tuesday & $\begin{array}{l}\text { 1. Turn in the paper, signed by all group members. } \\
\text { 2. Turn in the paper on a floppy or CD or Zip. } \\
\text { 3. Turn in the individual team member evaluations. } \\
\text { 4. Give your presentation ( } 10 \text { minutes }+5 \text { minutes for questions). } \\
\text { 5. Pick up your review papers. }\end{array}$ & \\
\hline & Wednesday & Have a great July 4th! & \\
\hline
\end{tabular}




\section{Appendix C}

\section{Evaluation Criteria and Checklist for Presentation and Paper on Cellular and Molecular Biology of Human Disease}

\begin{tabular}{|c|c|c|c|c|c|c|}
\hline Part of presentation & Criteria & Excellent & Very good & Good & Average & Poor \\
\hline \multicolumn{7}{|c|}{ In-class Presentation: Cell Biology of Human Disease } \\
\hline Introduction & $\begin{array}{l}\text { Was it clear how the talk would progress (can } \\
\text { be outline or just stated)? }\end{array}$ & & & & & \\
\hline \multirow{3}{*}{ Symptoms of Disease } & $\begin{array}{l}\text { What are the symptoms of patients with this } \\
\text { disease? }\end{array}$ & & & & & \\
\hline & Do the symptoms vary? In what way? & & & & & \\
\hline & $\begin{array}{l}\text { Is it clear that the presenters understand the } \\
\text { symptoms? }\end{array}$ & & & & & \\
\hline \multirow[t]{5}{*}{ General Cell Biology of Disease } & \multicolumn{6}{|c|}{ What organelle(s) and processes are affected and why does that defect lead to the disease? } \\
\hline & $\begin{array}{l}\text { What cellular structure or organelle (process) } \\
\text { is defective in patients with this disease? }\end{array}$ & & & & & \\
\hline & Briefly review the function of the organelle. & & & & & \\
\hline & $\begin{array}{l}\text { Why do defects in that organelle lead to the } \\
\text { disease? }\end{array}$ & & & & & \\
\hline & $\begin{array}{l}\text { What kinds of variations in symptoms exist? } \\
\text { What is the basis for that variation? }\end{array}$ & & & & & \\
\hline \multirow[t]{6}{*}{ Specific Gene Information } & \multicolumn{6}{|c|}{ How is the particular gene you are analyzing related to this disease? } \\
\hline & How was this gene identified? & & & & & \\
\hline & What does the gene product do? & & & & & \\
\hline & $\begin{array}{l}\text { What mutations in this gene are associated } \\
\text { with the disease? How is the disease inherited? }\end{array}$ & & & & & \\
\hline & $\begin{array}{l}\text { Is the gene present in nonhumans? If so, does it } \\
\text { perform the same function as in humans? }\end{array}$ & & & & & \\
\hline & $\begin{array}{l}\text { Are there any model organisms for the disease? } \\
\text { What do they reveal about the disease? }\end{array}$ & & & & & \\
\hline \multicolumn{7}{|c|}{ Above and Beyond: Exceptional presentations } \\
\hline & $\begin{array}{l}\text { Was any novel approach or interesting } \\
\text { anecdote given that would help the audience } \\
\text { remember this subject? }\end{array}$ & & & & & \\
\hline
\end{tabular}


Overheads/Demos, etc.

\begin{tabular}{|c|c|c|c|c|c|c|}
\hline & $\begin{array}{l}\text { Were overheads legible and easy to } \\
\text { follow? }\end{array}$ & & & & & \\
\hline & $\begin{array}{l}\text { Was the main topic clearly stated on the } \\
\text { overhead? }\end{array}$ & & & & & \\
\hline & Were lists of definitions provided? & & & & & \\
\hline Part of report & Criteria & Excellent & Very good & Good & Average & Poor \\
\hline
\end{tabular}

\section{Reports/Handouts: Cell Biology of Human Disease}

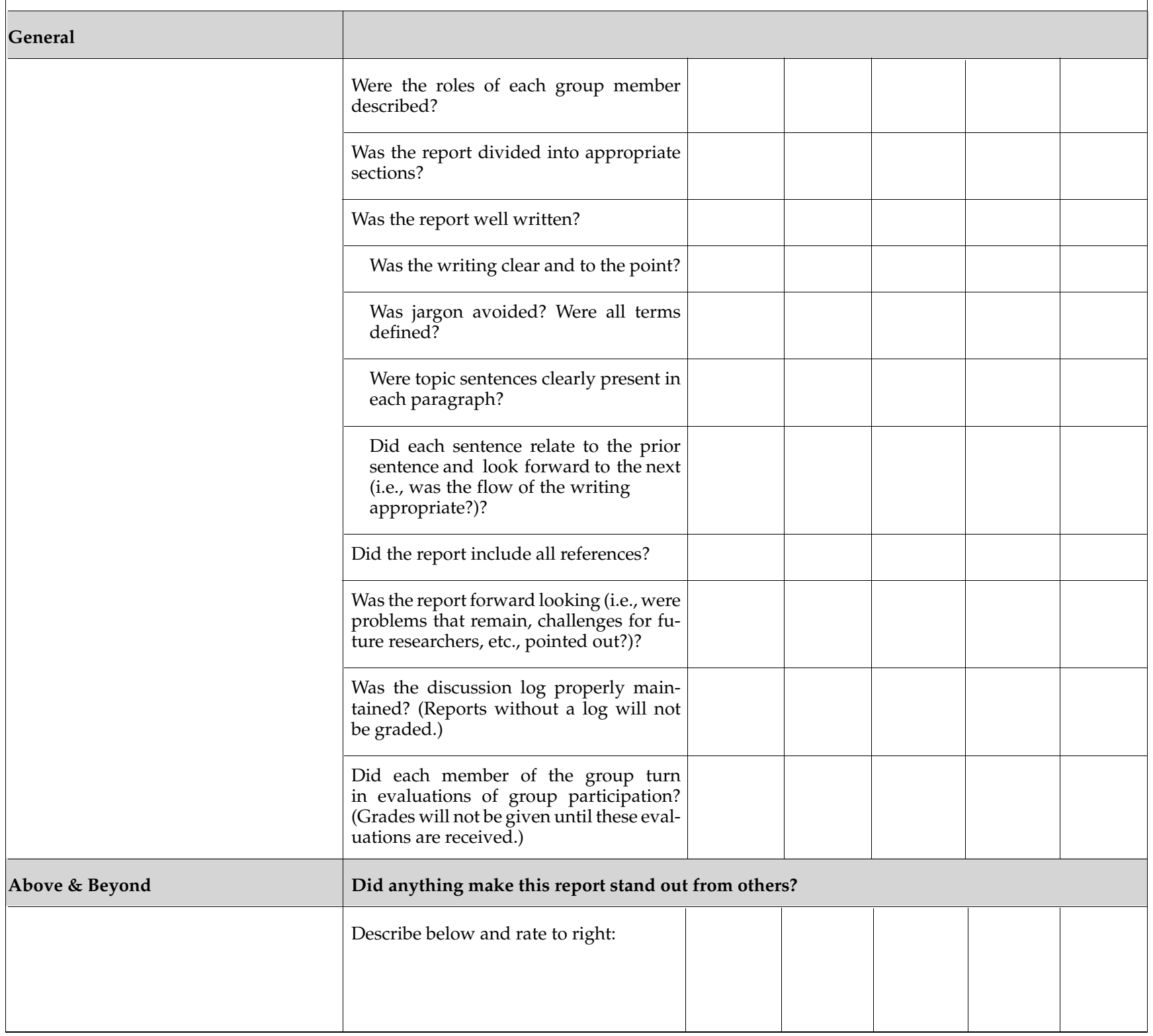




\section{Cellular and Molecular Biology of Disease Presentation Checklist \\ Presentation and Papers on Wednesday, July 18-Thursday, July 19}

\begin{tabular}{|c|c|c|c|}
\hline \multirow{7}{*}{$\begin{array}{l}\grave{\varpi} \\
\stackrel{\varpi}{\sigma} \\
\tilde{\sigma}\end{array}$} & Question & Answer & Check \\
\hline & When is it due? & $\begin{array}{l}\text { The completed paper is due at the beginning of class } \\
\text { on Wednesday. I need BOTH a hard copy and a } \\
\text { floppy (or CD or Zip). }\end{array}$ & \\
\hline & How long can it be? & $\begin{array}{l}\text { Paper should be ABOUT } 5 \text { pages long, single spaced, 12-point } \\
\text { font, 1-inch margins. It CAN be longer if necessary-I will } \\
\text { read everything you turn in and count it for your grade. The } \\
\text { references and any figures do not count in the page total. }\end{array}$ & \\
\hline & What is the format? & $\begin{array}{l}\text { The paper should be divided into clearly marked sections, cor- } \\
\text { responding to the evaluation checklist and to the parts of your } \\
\text { talk. You can modify the checklist to reflect your particular } \\
\text { organization or topics. }\end{array}$ & \\
\hline & $\begin{array}{l}\text { How do I indicate who wrote which } \\
\text { parts? }\end{array}$ & $\begin{array}{l}\text { The paper must include information about who wrote which } \\
\text { sections. You can put the name of the author in parentheses } \\
\text { after the heading. }\end{array}$ & \\
\hline & What about references? & $\begin{array}{l}\text { ALL references must be included, including web-based ref- } \\
\text { erences. You should have MORE than JUST text or web ref- } \\
\text { erences. I estimate that you should have about } 10 \text { references. } \\
\text { Web references in your paper should have the title of the site, } \\
\text { the URL, and the date you referenced it. } \\
\text { Example: } \\
\text { Mitochondria: architecture dictates function, } \\
\text { http://cellbio.utmb.edu/cellbio/mitoch1.htm, June 27, } 2001\end{array}$ & \\
\hline & $\begin{array}{l}\text { How do we document that the paper } \\
\text { represents joint work? }\end{array}$ & $\begin{array}{l}\text { The paper must be signed by all members of the group, stating, } \\
\text { "We have read the entire paper and had an opportunity to } \\
\text { make editing suggestions for all parts." }\end{array}$ & \\
\hline$\frac{\sqrt{n}}{\frac{\pi}{3}}$ & $\begin{array}{l}\text { When are my team member } \\
\text { evaluations due? }\end{array}$ & $\begin{array}{l}\text { You MUST TURN IN your team member evaluations together } \\
\text { with your paper at the beginning of class on July } 18 \text {. If these } \\
\text { evals are not included, your team paper will lose } 5 \text { points for } \\
\text { each day any evaluation is missing. }\end{array}$ & \\
\hline bo & $\begin{array}{l}\text { What do we do with our } \\
\text { project log? }\end{array}$ & $\begin{array}{l}\text { You MUST TURN IN your project log along with your paper. } \\
\text { The log should be a detailed journal of all the team activities- } \\
\text { I should be able to tell exactly what went on, who was late, } \\
\text { who left early, etc. }\end{array}$ & \\
\hline \multirow{2}{*}{ 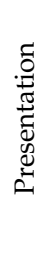 } & $\begin{array}{l}\text { How long do we have for our } \\
\text { presentation? }\end{array}$ & $\begin{array}{l}20 \text { minutes. You will have a warning at } 18 \text { minutes, then have } \\
2 \text { minutes to finish up. After } 20 \text { minutes, you will have to stop } \\
\text { talking. After the talk, you will have } 5 \text { minutes for questions. }\end{array}$ & \\
\hline & $\begin{array}{l}\text { How can I have my handouts } \\
\text { copied? }\end{array}$ & $\begin{array}{l}\text { You can make } 35 \text { copies of your handouts to bring with you on } \\
\text { Wednesday. Alternately, we will make copies for you IF YOU } \\
\text { BRING THE ORIGINALS BY 5:00 on TUESDAY, July 17, 2001, } \\
\text { to Wendy Rockhill in 248, Kincaid Hall (616-3383). }\end{array}$ & \\
\hline
\end{tabular}




\begin{tabular}{|c|c|c|c|}
\hline & Question & Answer & Check \\
\hline \multirow[t]{2}{*}{ 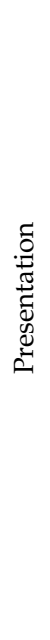 } & $\begin{array}{l}\text { What are we doing about } \\
\text { PowerPoint presentations? }\end{array}$ & $\begin{array}{l}\text { You are safest to stick with fonts such as Times, Arial (Geneva), } \\
\text { or Symbol. If you use an unusual font, please embed the font in } \\
\text { your presentation. You can do this by using the "Save as" func- } \\
\text { tion and checking "Embed font." Getting to the "Embed font" } \\
\text { command varies depending on the version of PowerPoint you } \\
\text { are using. } \\
\text { If you are using PowerPoint, you must bring your presentation } \\
\text { by 5:00, TUESDAY, July 17, to Robin Wright in } 238 \text { Kincaid Hall } \\
\text { (685-3651). You can bring it on a floppy, CD, or Zip disk. NOTE: } \\
\text { For Mac users, please use a PC-formatted floppy or Zip. You } \\
\text { can also ftp it, if you know the ftp address you need to access, } \\
\text { but again, you have to come to my office so we can get it onto } \\
\text { my computer ahead of time and make sure it is functioning. } \\
\text { To judge length of talk, estimate about one slide per minute. }\end{array}$ & \\
\hline & How can I practice my talk? & $\begin{array}{l}\text { Tentative: Kincaid Hall room } 114 \text { has been reserved for all day } \\
\text { on Tuesday, July } 17 \text { (about 8:00 until 5:00). To use the room, } \\
\text { come see Robin in } 238 \text { Kincaid. She will have a data projector } \\
\text { and computer that you can use for practice. }\end{array}$ & \\
\hline \multirow{3}{*}{ 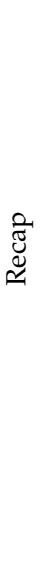 } & Tuesday, July 17 & $\begin{array}{l}\text { Get your PowerPoint presentation to Robin so she can load on } \\
\text { her computer. } \\
\text { Bring your handouts to Wendy so she can make copies for } \\
\text { you. } \\
\text { Double-check with Wendy or Robin to make sure that you } \\
\text { have everything you need for your presentation. }\end{array}$ & \\
\hline & Wednesday, July 18 & $\begin{array}{l}\text { 1. Turn in the paper, signed by all group members. } \\
\text { 2. Turn in the paper on a floppy or CD or Zip. } \\
\text { 3. Turn in the individual team member evaluations. } \\
\text { 4. Turn in the project log. } \\
\text { 5. Give your presentation ( } 20 \text { minutes }+5 \text { minutes for } \\
\text { questions). }\end{array}$ & \\
\hline & Thursday, July 19 & $\begin{array}{l}\text { Finish presentations. } \\
\text { Pick up your research paper and begin plans for next } \\
\text { presentation. }\end{array}$ & \\
\hline
\end{tabular}




\section{Appendix D}

\section{Evaluation Criteria and Checklist for Presentation and Paper on Recent Research on the Cellular Biology of Human Disease}

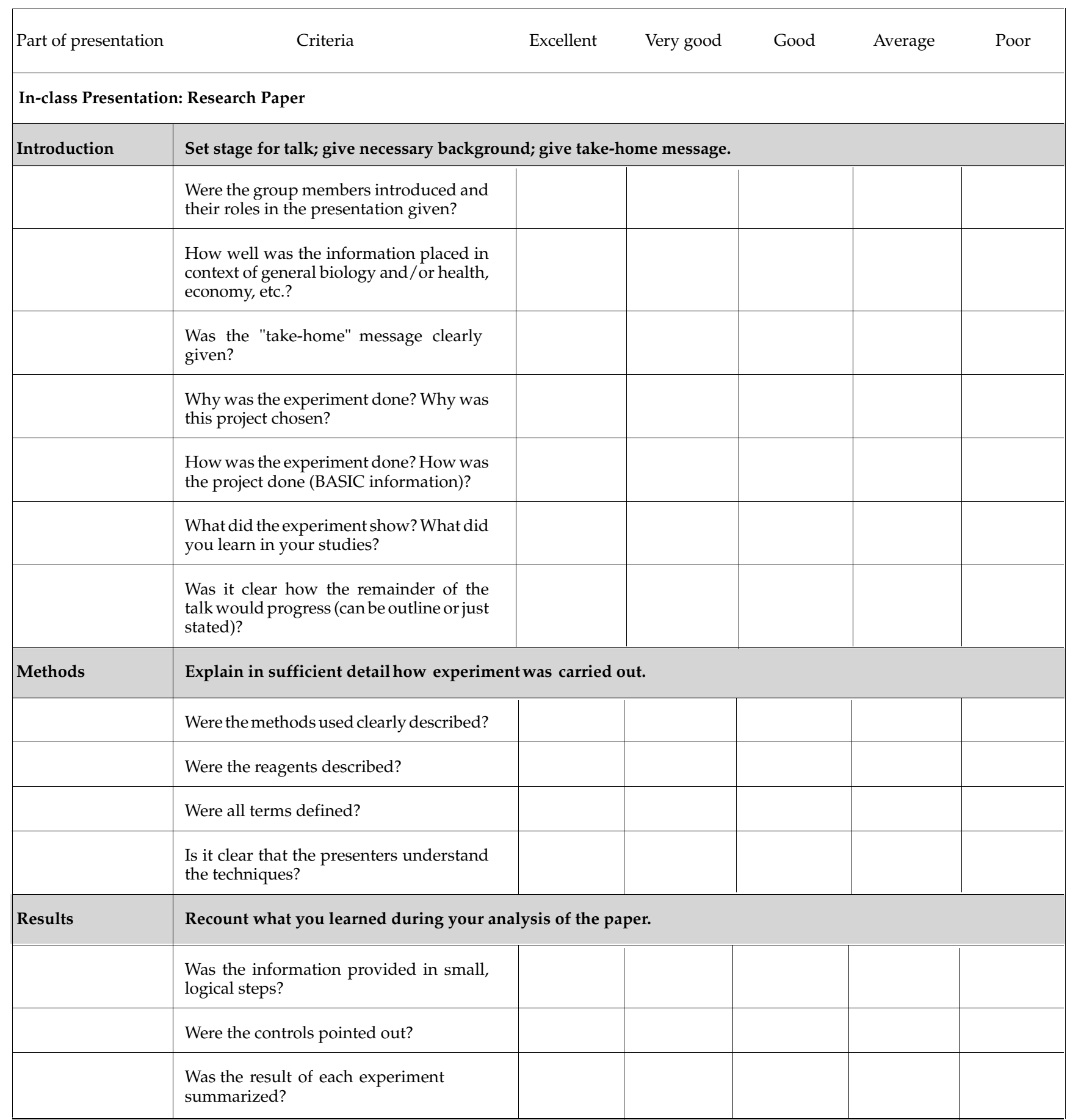




\begin{tabular}{|c|c|c|c|c|c|c|}
\hline Part of presentation & Criteria & Excellent & Very good & Good & Average & Poor \\
\hline \multirow[t]{4}{*}{ Conclusion, Summary } & \multicolumn{6}{|c|}{ Repeat take-home message; point out problems that are not yet resolved; give perspective and look to future. } \\
\hline & \multicolumn{6}{|l|}{ Was the overall take-home message repeated } \\
\hline & \multicolumn{6}{|l|}{$\begin{array}{l}\text { Were shortcomings of the experiment } \\
\text { pointed out? }\end{array}$} \\
\hline & \multicolumn{2}{|l|}{$\begin{array}{l}\text { Were one or two questions for future } \\
\text { experiments given? }\end{array}$} & & & & \\
\hline \multicolumn{7}{|c|}{ Above and Beyond: Exceptional presentations. } \\
\hline & \multicolumn{2}{|l|}{$\begin{array}{l}\text { Was any novel approach or interesting } \\
\text { anecdote given that would help the } \\
\text { audience remember this subject? }\end{array}$} & & & & \\
\hline \multicolumn{7}{|l|}{ Overheads/Demos, etc. } \\
\hline & \multicolumn{2}{|l|}{$\begin{array}{l}\text { Were overheads legible and easy to } \\
\text { follow? }\end{array}$} & & & & \\
\hline & \multicolumn{2}{|l|}{$\begin{array}{l}\text { Was the main topic clearly stated on } \\
\text { the overhead? }\end{array}$} & & & & \\
\hline \multicolumn{2}{|l|}{ Part of report } & Excellent & Very good & Good & Average & Poor \\
\hline \multicolumn{7}{|c|}{ Reports/Handouts: Research Paper } \\
\hline \multicolumn{7}{|l|}{ General } \\
\hline & \multicolumn{2}{|l|}{$\begin{array}{l}\text { Were the roles of each group member } \\
\text { described? }\end{array}$} & & & & \\
\hline & $\begin{array}{l}\text { Was the report divided into appropriate } \\
\text { sections (Introduction, Methods, Results, } \\
\text { and Conclusions)? }\end{array}$ & & & & & \\
\hline & Was the report well written? & & & & & \\
\hline & Was the writing clear and to the point? & & & & & \\
\hline & Was jargon avoided? & & & & & \\
\hline & $\begin{array}{l}\text { Were topic sentences clearly present in } \\
\text { each paragraph? }\end{array}$ & & & & & \\
\hline & $\begin{array}{l}\text { Did each sentence relate to the prior sen- } \\
\text { tence and look forward to the next (i.e., } \\
\text { was the flow of the writing appropriate?)? }\end{array}$ & & & & & \\
\hline
\end{tabular}




\begin{tabular}{|c|c|c|c|c|c|c|}
\hline Part of report & Criteria & Excellent & Very good & Good & Average & Poor \\
\hline & $\begin{array}{l}\text { Did the report include critical evaluations } \\
\text { of the information? }\end{array}$ & & & & & \\
\hline & Did the report include all references? & & & & & \\
\hline & $\begin{array}{l}\text { Was the discussion log properly main- } \\
\text { tained? (Reports without a log will not } \\
\text { be graded.) }\end{array}$ & & & & & \\
\hline Above \& Beyond & Did anything make this report stand out & om others? & & & & \\
\hline & Describe below and rate to right: & & & & & \\
\hline
\end{tabular}


Current Research Presentation Checklist

Presentation and Papers on Wednesday, August 8-Thursday, August 9

\begin{tabular}{|c|c|c|c|}
\hline \multirow{7}{*}{$\begin{array}{l}\overrightarrow{\tilde{\Xi}} \\
\stackrel{\vec{\sigma}}{c} \\
\text { f }\end{array}$} & Question & Answer & Check \\
\hline & When is it due? & $\begin{array}{l}\text { The completed paper is due at the beginning of class on Wednesday. I need } \\
\text { BOTH a hard copy and a floppy (or CD or Zip). }\end{array}$ & \\
\hline & How long it can be? & $\begin{array}{l}\text { Paper should be ABOUT } 5 \text { pages long, single spaced, 12-point font, 1-inch } \\
\text { margins. It CAN be longer if necessary-I will read everything you turn in } \\
\text { and count it for your grade. The references and any figures do not count } \\
\text { in the page total. }\end{array}$ & \\
\hline & What is the format? & $\begin{array}{l}\text { The paper should be divided into clearly marked sections, corresponding to } \\
\text { the evaluation checklist and to the parts of your talk. You can modify } \\
\text { the checklist to reflect your particular organization or topics. }\end{array}$ & \\
\hline & $\begin{array}{l}\text { How do I indicate } \\
\text { who wrote which parts? }\end{array}$ & $\begin{array}{l}\text { The paper must include information about who wrote which sections. You can } \\
\text { put the name of the author in parentheses after the heading. }\end{array}$ & \\
\hline & What about references? & $\begin{array}{l}\text { ALL references must be included, including web-based references. You should } \\
\text { have MORE than JUST text or web references. I estimate that you should } \\
\text { have about } 10 \text { references. Web references in your paper should have the title } \\
\text { of the site, the URL, and the date you referenced it. } \\
\text { Example: } \\
\text { Mitochondria: architecture dictates function, http://cellbio.utmb.edu/ } \\
\text { cellbio/mitoch1.htm, June } 27,2001\end{array}$ & \\
\hline & $\begin{array}{l}\text { How do we document that } \\
\text { the paper represents joint } \\
\text { work? }\end{array}$ & $\begin{array}{l}\text { The paper must be signed by all members of the group, stating, "We have } \\
\text { read the entire paper and had an opportunity to make editing suggestions } \\
\text { for all parts." }\end{array}$ & \\
\hline 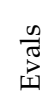 & $\begin{array}{l}\text { When are my team member } \\
\text { evaluations due? }\end{array}$ & $\begin{array}{l}\text { You MUST TURN IN your team member evaluations together with your } \\
\text { paper at the beginning of class on August } 8 \text {. If these evals are not included, your } \\
\text { team paper will lose } 5 \text { points for each day any evaluation is missing. }\end{array}$ & \\
\hline$\stackrel{\infty}{0}$ & $\begin{array}{l}\text { What do we do with our } \\
\text { project log? }\end{array}$ & $\begin{array}{l}\text { You MUST TURN IN your project log, along with your paper. The log } \\
\text { should be a detailed journal of all the team activities-I should be able to tell } \\
\text { exactly what went on,who was late, who left early, etc. }\end{array}$ & \\
\hline \multirow{2}{*}{ 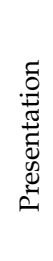 } & $\begin{array}{l}\text { How long do we have } \\
\text { for our presentation? }\end{array}$ & $\begin{array}{l}20 \text { minutes. You will have a warning at } 18 \text { minutes, then have } 2 \text { minutes to } \\
\text { finish up. After } 20 \text { minutes, you will have to stop talking. After the talk, you } \\
\text { will have } 5 \text { minutes for questions. }\end{array}$ & \\
\hline & $\begin{array}{l}\text { How can I have my } \\
\text { handouts copied? }\end{array}$ & $\begin{array}{l}\text { You can make } 35 \text { copies of your handouts to bring with you on } \\
\text { Wednesday. Alternately, we will make copies for you IF YOU BRING } \\
\text { THE ORIGINALS BY } 5: 00 \text { on TUESDAY, August 7, 2001, to Wendy Rockhill } \\
\text { in } 248 \text { Kincaid Hall (616-3383). }\end{array}$ & \\
\hline
\end{tabular}




\begin{tabular}{|c|c|c|c|}
\hline 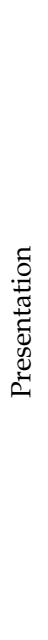 & $\begin{array}{l}\text { What are we doing about } \\
\text { PowerPoint presentations? }\end{array}$ & $\begin{array}{l}\text { You are safest to stick with fonts such as Times, Arial (Geneva), } \\
\text { or Symbol. If you use an unusual font, please embed the font in } \\
\text { your presentation. You can do this by using the "Save as" } \\
\text { function and checking "Embed font." Getting to the TMEmbed } \\
\text { font } \int \text { command varies depending on the version of PowerPoint } \\
\text { you are using. } \\
\text { If you are using PowerPoint, you must bring your presentation } \\
\text { by 5:00, TUESDAY, August } 7 \text { to Robin Wright in } 238 \text { Kincaid } \\
\text { Hall (685-3651). You can bring it on a floppy, CD, or Zip disk. } \\
\text { NOTE: For Mac users, please use a PC-formatted floppy } \\
\text { or Zip. You can also ftp it, if you know the ftp address you need } \\
\text { to access, but again, you have to come to my office so we can get it } \\
\text { onto my computer ahead of time and make sure it is functioning. } \\
\text { To judge length of talk, estimate about one slide per minute. }\end{array}$ & \\
\hline \multirow[b]{2}{*}{$\begin{array}{l}\text { च् } \\
\stackrel{\mathscr{U}}{\simeq}\end{array}$} & Tuesday, August 7 & $\begin{array}{l}\text { Get your PowerPoint presentation to Robin so she can load on } \\
\text { her computer. } \\
\text { Bring your handouts to Wendy so she can make copies for you. } \\
\text { Double-check with Wendy or Robin to make sure that you have } \\
\text { everything you need for your presentation. }\end{array}$ & \\
\hline & Wednesday, August 8 & $\begin{array}{l}\text { 1. Turn in the paper, signed by all group members. } \\
\text { 2. Turn in the paper on a floppy or CD or Zip. } \\
\text { 3. Turn in the individual team member evaluations. } \\
\text { 4. Turn in the project log. } \\
\text { 5. Give your presentation ( } 20 \text { minutes }+5 \text { minutes for } \\
\text { questions). }\end{array}$ & \\
\hline
\end{tabular}




\section{Appendix E}

\section{Diseases and References Used in Project-Based Cell Biology Class (2000-2001) ${ }^{a, b}$}

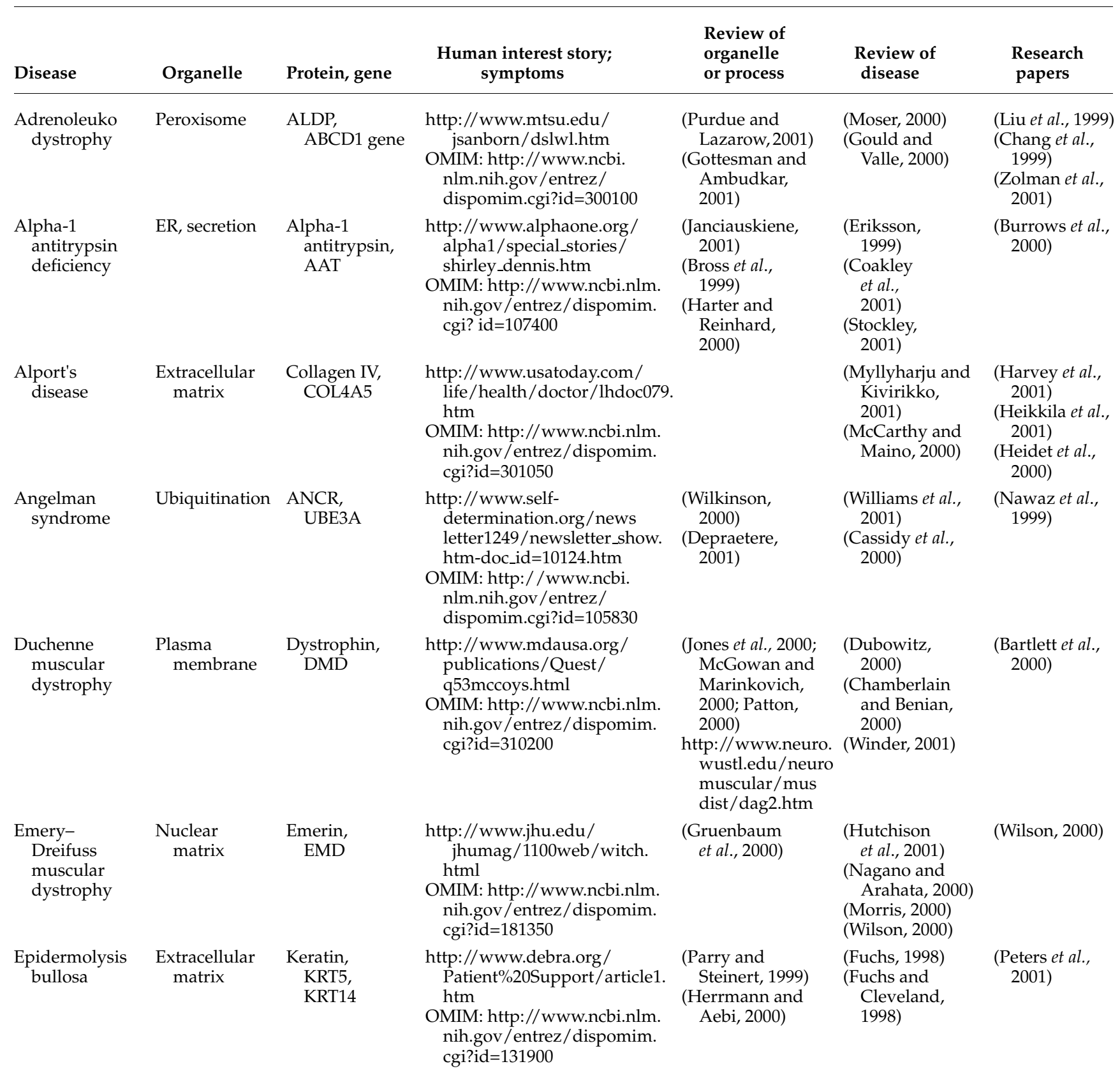




\begin{tabular}{|c|c|c|c|c|c|c|}
\hline Disease & Organelle & Protein, gene & $\begin{array}{l}\text { Human interest story; } \\
\text { symptoms }\end{array}$ & $\begin{array}{l}\text { Review of } \\
\text { organelle } \\
\text { or process }\end{array}$ & $\begin{array}{l}\text { Review of } \\
\text { disease }\end{array}$ & $\begin{array}{c}\text { Research } \\
\text { papers }\end{array}$ \\
\hline $\begin{array}{l}\text { Machado- } \\
\text { Joseph } \\
\text { disease }\end{array}$ & $\begin{array}{l}\text { Ubiquitin- } \\
\text { like protein }\end{array}$ & $\begin{array}{l}\text { Ataxin 3, } \\
\text { ATX3 }\end{array}$ & $\begin{array}{l}\text { http://irmas.freeyellow.com/ } \\
\text { index.html } \\
\text { http://ijdfnonprofit.freeyellow. } \\
\text { com/newfile.html } \\
\text { OMIM: http://www.ncbi.nlm. } \\
\text { nih.gov/entrez/dispomim. } \\
\text { cgi?id=109150 }\end{array}$ & $\begin{array}{l}\text { (Johnson, 2000) } \\
\text { (Weissman, } \\
\text { 2001) } \\
\text { (Mayer, 2000) } \\
\end{array}$ & $\begin{array}{l}\text { (Yamada et al., } \\
\text { 2000). } \\
\text { (Evidente } \\
\text { et al., 2000) }\end{array}$ & $\begin{array}{l}\text { (Chan et al., } \\
\text { 2000; Warrick } \\
\text { et al., 1999) } \\
\text { (Davidson } \\
\text { et al., 2000) }\end{array}$ \\
\hline $\begin{array}{l}\text { Tay-Sachs } \\
\text { disease }\end{array}$ & Lysosomes & $\begin{array}{l}\text { Hexos } \\
\text { aminadase, } \\
\text { HEXA }\end{array}$ & $\begin{array}{l}\text { http://www.geocities.com/ } \\
\text { enchantedforest/pond/ } \\
\text { 3061/colton.html } \\
\text { OMIM: http://www.ncbi.nlm. } \\
\text { nih.gov/entrez/dispomim. } \\
\text { cgi?id=272800 }\end{array}$ & & $\begin{array}{l}\text { (Mahuran, } \\
\text { 1999) } \\
\text { (Okada and } \\
\text { O'Brien, 2001) } \\
\text { (Suzuki, 2001) }\end{array}$ & $\begin{array}{l}\text { (Adamali et al., } \\
\text { 1999) } \\
\text { (Guidotti et al., } \\
\text { 1999) }\end{array}$ \\
\hline
\end{tabular}

${ }^{a}$ Abbreviations: ALDP $=$ X-linked adrenolcukodystrophy protein; OMIM = Online Mendelian Inheritance in Man (web site); ANCR = Angelman Syndrome Chromosomal Region; ER = endoplasmic reticulum; NOG = noggin.

${ }^{b}$ References:

Adamali, H.I., Somani, I.H., Huang, J.Q., Mahuran, D., Gravel, R.A., Trasler, J.M., and Hermo, L. (1999). I. Abnormalities in cells of the testis, efferent ducts, and epididymis in juvenile and adult mice with beta-hexosaminidase A and B deficiency. J Androl. 20, 779-802.

Bartlett, R.J., Stockinger, S., Denis, M.M., Bartlett, W.T., Inverardi, L., Le, T.T., thi Man, N., Morris, G.E., Bogan, D.J., Metcalf-Bogan, J., and Kornegay, J.N. (2000). In vivo targeted repair of a point mutation in the canine dystrophin gene by a chimericRNA/DNA oligonucleotide. Nat. Biotechnol. 18, 615-622.

Bross, P., Corydon, T.J., Andresen, B.S., Jorgensen, M.M., Bolund, L., and Gregersen, N. (1999). Protein misfolding and degradation in genetic diseases. Hum. Mutat. 14, 186-198.

Burrows, J.A., Willis, L.K., and Perlmutter, D.H. (2000). Chemical chaperones mediate increased secretion of mutant alpha1-antitrypsin (alpha 1-AT) Z: a potential pharmacological strategy for prevention of liver injury and emphysema in alpha 1-AT deficiency. Proc. Natl. Acad. Sci. USA 97, 1796-1801.

Cassidy, S.B., Dykens, E., and Williams, C.A. (2000). Prader-Willi and Angelman syndromes: sister imprinted disorders. Am. J. Med.Genet. 97, 136-146.

Chamberlain, J.S., and Benian, G.M. (2000). Muscular dystrophy: the worm turns to genetic disease. Curr. Biol. 10, R795-R797.

Chan, H.Y., Warrick, J.M., Gray-Board, G.L., Paulson, H.L., and Bonini, N.M. (2000). Mechanisms of chaperone suppression of polyglutamine disease: selectivity, synergy and modulation of protein solubility in Drosophila. Hum. Mol. Genet. 9, 2811-2820.

Chang, C.C., Warren, D.S., Sacksteder, K.A., and Gould, S.J. (1999). PEX12 interacts with PEX5 and PEX10 and acts downstream of receptor docking in peroxisomal matrix protein import. J. Cell. Biol. 147, 761-774.

Christian, J.L. (2000). BMP, Wnt and Hedgehog signals: how far can they go? Curr. Opin. Cell. Biol. 12, $244-249$.

Coakley, R.J., Taggart, C., O'Neill, S., and McElvaney, N.G. (2001). Alpha1-antitrypsin deficiency: biological answers to clinical questions. Am. J. Med. Sci. 321, 33-41. 
Davidson, J.D., Riley, B., Burright, E.N., Duvick, L.A., Zoghbi, H.Y., and Orr, H.T. (2000). Identification and characterization of an ataxin-1interacting protein: A1Up, a ubiquitin-like nuclear protein. Hum. Mol. Genet. 9, 2305-2312.

Depraetere, V. (2001). Getting activated with poly-ubiquitination. Nat. Cell Biol. 3, E181.

Dixon, J., Brakebusch, C., Fassler, R., and Dixon, M.J. (2000). Increased levels of apoptosis in the prefusion neural folds underlie the craniofacial disorder, Treacher Collins syndrome. Hum. Mol. Genet. 9, 1473-1480.

Dubowitz, V. (2000). Congenital muscular dystrophy: an expanding clinical syndrome. Ann. Neurol. 47, 143-144.

Enriquez, J.A., Cabezas-Herrera, J., Bayona-Bafaluy, M.P., and Attardi, G. (2000). Very rare complementation between mitochondria carrying different mitochondrial DNA mutations points to intrinsic genetic autonomy of the organelles in cultured human cells. J. Biol. Chem. 275, 11207-11215.

Eriksson, S. (1999). Alpha 1-antitrypsin deficiency. J. Hepatol. 30(Suppl 1), 34-39.

Evidente, V.G., Gwinn-Hardy, K.A., Caviness, J.N., and Gilman, S. (2000). Hereditary ataxias. Mayo. Clin. Proc. 75, $475-490$.

Fuchs, E. (1998). Beauty is skin deep: the fascinating biology of the epidermis and its appendages. Harvey Lect. 94, 47-77.

Fuchs, E., and Cleveland, D.W. (1998). A structural scaffolding of intermediate filaments in health and disease. Science. $279,514-519$.

Gottesman, M.M., and Ambudkar, S.V. (2001). Overview: ABC transporters and human disease. J. Bioenerg. Biomembr. 33, $453-458$.

Gould, S.J., and Valle, D. (2000). Peroxisome biogenesis disorders: genetics and cell biology. Trends Genet. 16, 340-345.

Gruenbaum, Y., Wilson, K.L., Harel, A., Goldberg, M., and Cohen, M. (2000). Review: nuclear lamins—structural proteins with fundamental functions. J. Struct. Biol. 129, 313-323.

Guidotti, J.E., Mignon, A., Haase, G., Caillaud, C., McDonell, N., Kahn, A., and Poenaru, L. (1999). Adenoviral gene therapy of the Tay-Sachs disease in hexosaminidase A-deficient knock-out mice. Hum. Mol. Genet. 8, 831-838.

Harter, C., and Reinhard, C. (2000). The secretory pathway from history to the state of the art. Subcell. Biochem. 34, 1-38.

Harvey, S.J., Mount, R., Sado, Y., Naito, I., Ninomiya, Y., Harrison, R., Jefferson, B., Jacobs, R., and Thorner, P.S. (2001). The inner ear of dogs with X-linked nephritis provides clues to the pathogenesis of hearing loss in X-linked Alport syndrome. Am. J. Pathol. 159, 1097-1104.

Heidet, L., Cai, Y., Guicharnaud, L., Antignac, C., and Gubler, M.C. (2000). Glomerular expression of type IV collagen chains in normal and X-linked Alport syndrome kidneys. Am. J. Pathol. 156, 1901-1910.

Heikkila, P., Tibell, A., Morita, T., Chen, Y., Wu, G., Sado, Y., Ninomiya, Y., Pettersson, E., and Tryggvason, K. (2001). Adenovirus-mediated transfer of type IV collagen alpha5 chain cDNA into swine kidney in vivo: deposition of the protein into the glomerular basement membrane. Gene Ther. 8, 882-890.

Helvering, L.M., Sharp, R.L., Ou, X., and Geiser, A.G. (2000). Regulation of the promoters for the human bone morphogenetic protein 2 and 4 genes. Gene 256, 123-138.

Herrmann, H., and Aebi, U. (2000). Intermediate filaments and their associates: multi-talented structural elements specifying cytoarchitecture and cytodynamics. Curr. Opin. Cell Biol. 12, 79-90.

Howell, N. (1999). Human mitochondrial diseases: answering questions and questioning answers. Int. Rev. Cytol. 186, $49-116$.

Hutchison, C.J., Alvarez-Reyes, M., and Vaughan, O.A. (2001). Lamins in disease: why do ubiquitously expressed nuclear envelope proteins give rise to tissue-specific disease phenotypes? J. Cell Sci. 114, 9-19.

Isaac, C., Marsh, K.L., Paznekas, W.A., Dixon, J., Dixon, M.J., Jabs, E.W., and Meier, U.T. (2000). Characterization of the nucleolar gene product, treacle, in Treacher Collins syndrome. Mol. Biol. Cell. 11, 3061-3071.

James, A.M., Sheard, P.W., Wei, Y.H., and Murphy, M.P. (1999). Decreased ATP synthesis is phenotypically expressed during increased energy demand in fibroblasts containing mitochondrial tRNA mutations. Eur. J. Biochem. 259, 462-469.

Janciauskiene, S. (2001). Conformational properties of serine proteinase inhibitors (serpins) confer multiple pathophysiological roles. Biochim. Biophys. Acta 1535, 221-235.

Johnson, W.G. (2000). Late-onset neurodegenerative diseases-the role of protein insolubility. J. Anat. 196(Pt. 4), 609-616.

Jones, J.C., Dehart, G.W., Gonzales, M., and Goldfinger, L.E. (2000). Laminins: an overview. Microsc. Res. Tech. 51, $211-213$.

Liu, L.X., Janvier, K., Berteaux-Lecellier, V., Cartier, N., Benarous, R., and Aubourg, P. (1999). Homo- and heterodimerization of peroxisomal ATP-binding cassette half-transporters. J. Biol. Chem. 274, 32738-32743.

Mahuran, D.J. (1999). Biochemical consequences of mutations causing the GM2 gangliosidoses. Biochim. Biophys. Acta 1455, $105-138$.

Marsh, K.L., and Dixon, M.J. (2000). Treacher Collins syndrome. Adv. Otorhinolaryngol. 56, 53-59.

Mayer, R.J. (2000). The meteoric rise of regulated intracellular proteolysis. Nat. Rev. Mol. Cell Biol. 1, 145-148.

McCarthy, P.A., and Maino, D.M. (2000). Alport syndrome: a review. Clin. Eye Vis. Care 12, 139-150.

McGowan, K.A., and Marinkovich, M.P. (2000). Laminins and human disease. Microsc. Res. Tech. 51, 262-279.

Miyazono, K., Kusanagi, K., and Inoue, H. (2001). Divergence and convergence of TGF-beta/BMP signaling. J. Cell. Physiol. 187, 265-276.

Morris, G.E. (2000). Nuclear proteins and cell death in inherited neuromuscular disease. Neuromuscul. Disord. 10, $217-227$.

Moser, H.W. (2000). Molecular genetics of peroxisomal disorders. Front. Biosci. 5, D298-D306.

Myllyharju, J., and Kivirikko, K.I. (2001). Collagens and collagen-related diseases. Ann. Med. 33, 7-21.

Nagano, A., and Arahata, K. (2000). Nuclear envelope proteins and associated diseases. Curr. Opin. Neurol. 13, 533-539.

Nakayama, T., Cui, Y., and Christian, J.L. (2000). Regulation of BMP/Dpp signaling during embryonic development. Cell. Mol. Life. Sci. 57, 943-956.

Nawaz, Z., Lonard, D.M., Smith, C.L., Lev-Lehman, E., Tsai, S.Y., Tsai, M.J., and O'Malley, B.W. (1999). The Angelman syndrome-associated protein, E6-AP, is a coactivator for the nuclear hormone receptor superfamily. Mol. Cell. Biol. 19, 1182-1189.

Okada, S., and O'Brien, J.S. (2001). Discovery of beta-hexosaminidase A deficiency in Tay-Sachs disease. Adv. Genet. 44, 61-66.

Orth, M., and Schapira, A.H. (2001). Mitochondria and degenerative disorders. Am. J. Med. Genet. 106, $27-36$.

Parry, D.A., and Steinert, P.M. (1999). Intermediate filaments: molecular architecture, assembly, dynamics and polymorphism. Q. Rev. Biophys. 32, 99-187.

Patton, B.L. (2000). Laminins of the neuromuscular system. Microsc. Res. Tech. 51, 247-261.

Peters, B., Kirfel, J., Bussow, H., Vidal, M., and Magin, T.M. (2001). Complete cytolysis and neonatal lethality in keratin 5 knockout mice reveal its fundamental role in skin integrity and in epidermolysis bullosa simplex. Mol. Biol. Cell. 12, 1775-1789.

Purdue, P.E., and Lazarow, P.B. (2001). Peroxisome biogenesis. Annu. Rev. Cell Dev. Biol. 17, 701-752.

Reddi, A.H. (1997). BMPs: actions in flesh and bone. Nat. Med. 3, 837-839.

Schwarzacher, H. G., and Mosgoeller, W. (2000). Ribosome biogenesis in man: current views on nucleolar structures and function. Cytogenet. Cell Genet. 91, 243-252. 
Splendore, A., Silva, E.O., Alonso, L.G., Richieri-Costa, A., Alonso, N., Rosa, A., Carakushanky, G., Cavalcanti, D.P., Brunoni, D., and PassosBueno, M.R. (2000). High mutation detection rate in TCOF1 among Treacher Collins syndrome patients reveals clustering of mutations and 16 novel pathogenic changes. Hum. Mutat. 16, 315-322.

Stockley, R.A. (2001). Proteases and antiproteases. Novartis Found. Symp. 234, 189-199; discussion 199-204.

Suzuki, K. (2001). Recognition and delineation of beta-hexosaminidase alpha-chain variants: a historical and personal perspective. Adv. Genet. $44,173-184$.

Thorburn, D.R., and Dahl, H.H. (2001). Mitochondrial disorders: genetics, counseling, prenatal diagnosis and reproductive options. Am. J. Med. Genet. 106, 102-114.

Warrick, J.M., Chan,H.Y., Gray-Board, G.L., Chai, Y., Paulson, H.L., and Bonini, N.M. (1999). Suppression of polyglutamine-mediated neurodegeneration in Drosophila by the molecular chaperone HSP70. Nat. Genet. 23, 425-428.

Weissman, A.M. (2001). Themes and variations on ubiquitylation. Nat. Rev. Mol. Cell. Biol. 2, 169-178.

Wilkinson, K.D. (2000). Ubiquitination and deubiquitination: targeting of proteins for degradation by the proteasome. Semin. Cell Dev. Biol. $11,141-148$.

Williams, C.A., Lossie, A., and Driscoll, D. (2001). Angelman syndrome: mimicking conditions and phenotypes. Am. J. Med. Genet. 101, 59-64. Wilson, K.L. (2000). The nuclear envelope, muscular dystrophy and gene expression. Trends. Cell Biol. 10, 125-129.

Winder, S.J. (2001). The complexities of dystroglycan. Trends Biochem. Sci. 26, 118-124.

Yamada, M., Tsuji, S., and Takahashi, H. (2000). Pathology of CAG repeat diseases. Neuropathology 20, 319-325.

Yasukawa, T., Suzuki, T., Ishii, N., Ohta, S., and Watanabe, K. (2001). Wobble modification defect in tRNA disturbs codon-anticodon interaction in a mitochondrial disease. EMBO J. 20, 4794-4802.

Zolman, B.K., Silva, I.D., and Bartel, B. (2001). The Arabidopsis pxa1 mutant is defective in an ATP-binding cassette transporter-like protein required for peroxisomal fatty acid beta-oxidation. Plant. Physiol. 127, 1266-1278. 


\section{Appendix F}

\section{Example of Guided Activity to Help Teams Plan and Organize Their Efforts}

1. Imagine that you are sent into a room to give the news to a patient (or the patient's parents) that he or she (or their child) has the disease you are studying. What questions would this person (or people) ask you about the disease?

2. Imagine that you are presenting the cell and molecular biology of your disease to other UW [University of Washington] biology students. What questions would they ask you about this disease?

3. Imagine that you are talking to the most famous and important researchers in the world working on your disease. What would you ask them about this disease?

4. Arrange the three types of questions into a logical outline. Use the project checklist to help you organize this information If you feel that the project checklist should be changed to reflect your particular ideas, discuss it with Robin. THIS IS ONE OF THE MOST IMPORTANT STEPS. Be sure you have a clear idea of WHAT you want your paper and presentation to answer about your disease.

5. What key events must occur for you to prepare your paper and presentation? What are the steps in order? When should each be completed? Who is responsible and what are those responsibilities?

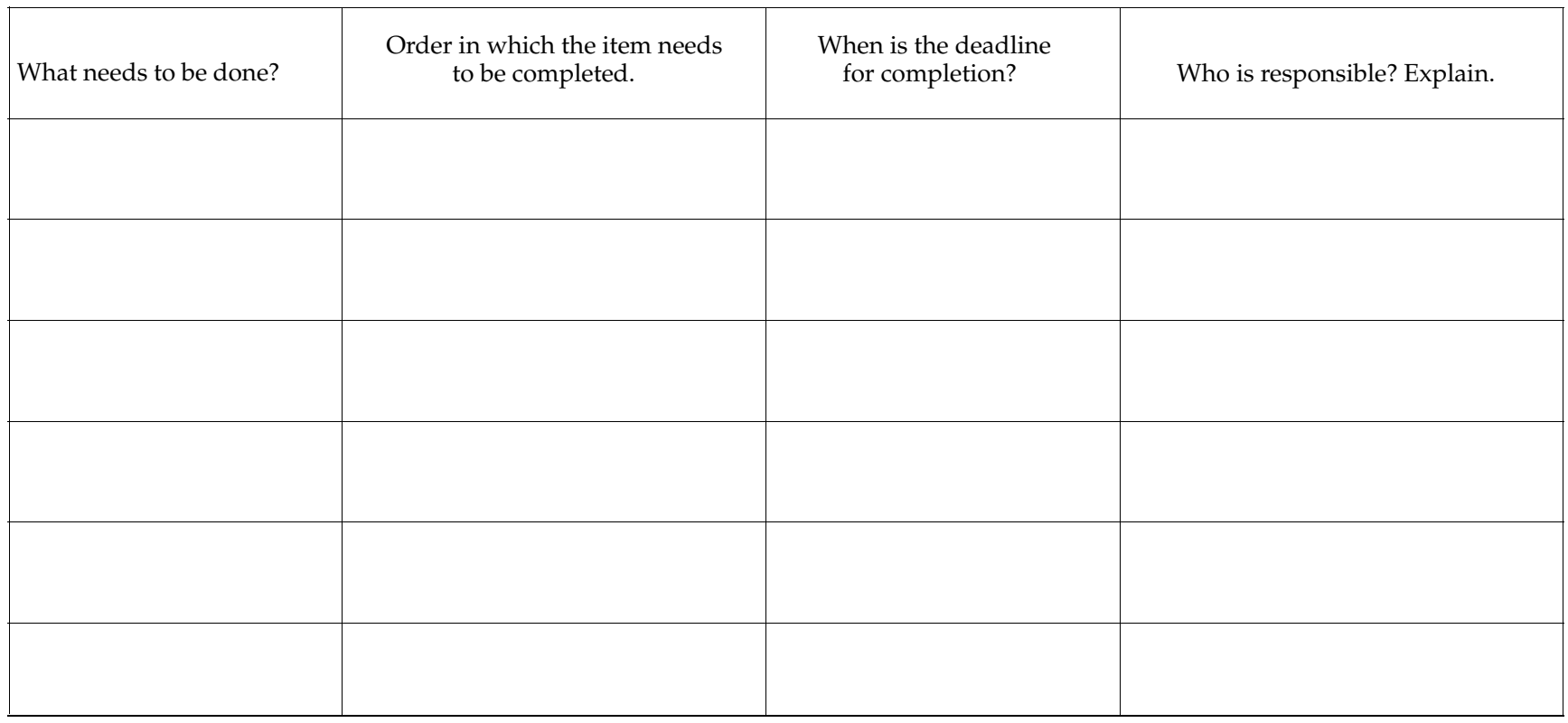




\section{Appendix G}

\section{Comparison Chart of Features of Human Diseases}

\begin{tabular}{|c|c|c|c|c|}
\hline Genetics & 1: EDMD & 2: MJD & 3: TCS & 4: ALD \\
\hline \multicolumn{5}{|l|}{ Gene(s) name } \\
\hline \multicolumn{5}{|l|}{ Chromosomal location } \\
\hline \multicolumn{5}{|l|}{$\begin{array}{l}\text { Inheritance (autosomal? X-linked? } \\
\text { dominant or recessive?) }\end{array}$} \\
\hline \multicolumn{5}{|l|}{$\begin{array}{l}\text { In what types of cells and } \\
\text { when is gene expressed? }\end{array}$} \\
\hline \multicolumn{5}{|l|}{ Number \& types of mutations } \\
\hline \multicolumn{5}{|l|}{$\begin{array}{l}\text { Evolutionarily conserved? } \\
\text { To what degree? }\end{array}$} \\
\hline Protein & 1: EDMD & 2: MJD & 3: TCS & 4: ALD \\
\hline \multicolumn{5}{|l|}{ Size, number of amino acids? } \\
\hline \multicolumn{5}{|l|}{ Location of protein in the cell } \\
\hline \multicolumn{5}{|l|}{ Protein binds to or interacts with ... } \\
\hline \multicolumn{5}{|l|}{ Structural features of protein } \\
\hline \multicolumn{5}{|l|}{ Protein function } \\
\hline \multicolumn{5}{|l|}{$\begin{array}{l}\text { In what classes of organisms is } \\
\text { this protein found? Explain. }\end{array}$} \\
\hline Organismal features of disease & 1: EMDM & 2: MJD & 3: TCS & 4: ALD \\
\hline \multicolumn{5}{|l|}{$\begin{array}{l}\text { What are the major symptoms } \\
\text { of disease in LAY TERMS? }\end{array}$} \\
\hline \multicolumn{5}{|l|}{ Related genetic diseases? } \\
\hline \multicolumn{5}{|l|}{ What types of cells are affected? Why? } \\
\hline \multicolumn{5}{|l|}{ Unusual features of disease } \\
\hline \multicolumn{5}{|l|}{ Animal models for disease } \\
\hline Cellular $\&$ molecular biology of disease & 1: EMDM & 2: MJD & 3: TCS & 4: ALD \\
\hline \multicolumn{5}{|l|}{$\begin{array}{l}\text { What organelle or process is affected } \\
\text { in this disease? What is the normal } \\
\text { function of this organelle or process? }\end{array}$} \\
\hline \multicolumn{5}{|l|}{$\begin{array}{l}\text { In what types of cells, organisms, } \\
\text { kingdoms, etc., is this organelle } \\
\text { (process) found? What evolutionary } \\
\text { variations exist? }\end{array}$} \\
\hline \multicolumn{5}{|l|}{$\begin{array}{l}\text { How do the mutations alter function } \\
\text { of the organelle or process, resulting } \\
\text { in disease symptoms? What is the } \\
\text { connection between the mutation } \\
\text { and the symptoms? }\end{array}$} \\
\hline Relationships to your disease & 1: EDMD & 2: MJD & 3: TCS & 4: ALD \\
\hline $\begin{array}{l}\text { Compare and contrast features of } \\
\text { this disease to the one you are } \\
\text { researching. }\end{array}$ & & & & \\
\hline
\end{tabular}




\section{Appendix $\mathbf{H}$}

\section{Assessment}

Data are taken from anonymous course evaluation forms completed at the end of the summer 2001 quarter. Thirty students responded, but not all questions were answered by all students. For some questions, an individual may have reported more than one answer. In these cases, all of the answers were used. Examples of statements were randomly chosen from answers that contained complete thoughts rather just a "yes" or "no" answer.

What are your career goals?

\begin{tabular}{cccc}
\hline Medicine; dentistry; & Research; graduate & Other (teacher; & Undecided \\
pharmacy & school & 9 & 3 \\
10 & $(33 \%)$ & $(19 \%)$ & $(11 \%)$ \\
$(37 \%)$ & ecologist; law school) & 5 \\
\hline
\end{tabular}

How do you think this class will help you be successful in your career?

\begin{tabular}{ccc}
\hline Developed better writing, \\
communication, presentation \\
skills & Learned how to approach & Helped learn how to work \\
in teams & 6 \\
$(44 \%)$ & research, evaluate data, learn & 6 \\
$(22 \%)$ & $(33 \%)$ & $(20)$ \\
\hline
\end{tabular}

How did you initially feel about the focus of this class on team effort rather than individual effort?

\begin{tabular}{ccc}
\hline Positive & Mixed & Negative \\
16 & 4 & 10 \\
$(53 \%)$ & $(13 \%)$ & $(33 \%)$
\end{tabular}

I was initially excited at first with the idea of working in a team because I like working with a small group and thought that this would lighten the course work per person.

I did not like the format because I don't like depending on other people's performance for my own grade.

I didn't think it was as valuable as I do now. It concerned me a little about group work time that would be required-how that might work.

Liked it a lot; I enjoy teamwork to combine my ideas.

Initially I was a little worried since sometimes groups can be challenging and frustrating!

Part of me was stoked because there weren't any big tests, but another part of me was pissed because attendance affected my grade.

I liked it and I didn't like it. I liked it because I thought the class would be more interactive \& I would learn more; I didn't like it because I didn't want my grade to depend on others' work.

I thought it was a relief!

I thought it would be interesting, but I was a little wary of working in groups because they can be hard to work with.

I liked the concept initially. It sounded great because it was unlike any other class I had taken here.

I was looking forward to it until we got our first presentation grade. At that moment, I wished we didn't work in group. 
If you could go back in time to the beginning of the quarter and give yourself some advice about how to take best advantage of this class, what would you tell yourself?

\begin{tabular}{|c|c|c|c|}
\hline $\begin{array}{c}\text { Plan more effectively } \\
12 \\
(41 \%)\end{array}$ & $\begin{array}{c}\text { Prepare to work hard; } \\
\text { set aside enough time; } \\
\text { spend more time } \\
\text { in the library } \\
8 \\
(28 \%)\end{array}$ & $\begin{array}{c}\text { Get to know other } \\
\text { team members } \\
7 \\
(24 \%)\end{array}$ & $\begin{array}{l}\text { Other (be ready to learn } \\
\text { from diverse groups } \\
\text { and people; concentrate } \\
\text { on learning in depth) } \\
2 \\
(7 \%)\end{array}$ \\
\hline
\end{tabular}

What was the most important skill, attitude, or action for making your team work effectively?

\begin{tabular}{cccc}
\hline $\begin{array}{c}\text { Flexibility; ability to } \\
\text { compromise }\end{array}$ & $\begin{array}{c}\text { Positive attitude; } \\
\text { having fun }\end{array}$ & $\begin{array}{c}\text { Other (patience; hard } \\
\text { work; respect) }\end{array}$ & $\begin{array}{c}\text { Good communication } \\
\text { skills } \\
12\end{array}$ \\
$(33 \%)$ & $(25 \%)$ & $(22 \%)$ & 7 \\
$(19 \%)$ & \\
\hline
\end{tabular}

As we have discussed, we traded breadth for depth in this class. Please comment on the value and trade-offs of this decision.

$\begin{array}{ccc} & \begin{array}{c}\text { Wished there were more time to } \\ \text { learn about other diseases and } \\ \text { general cell biology; worried } \\ \text { about preparation for } \\ \text { other classes }\end{array} & \begin{array}{c}\text { Depth allowed learning how } \\ \text { to read research papers and } \\ \text { approach complex } \\ \text { biological } \\ \text { problem }\end{array} \\ \begin{array}{c}\text { learned a lot } \\ 18\end{array} & 9 & 6 \\ (55 \%) & (27 \%) & (18 \%)\end{array}$

I liked the way it was set up because I think the skills and techniques I learned and making presentations and posters are much better than learning the facts about the diseases. Now, I can learn all about them on my own.

I think it was great. I never learned so much in one quarter, ironically, since we only studied one disease. But even hearing other people talk helped me learn about their topics.

I'm a little worried that I won't be prepared for the lab for this class. [a separate cell biology laboratory course]

By researching a more defined topic more in-depth, I learned the process of researching a complex problem/disease in addition to the problem [itself]. I would not have learned this if we had studied more for breadth. However, I am not very familiar with other organelles and diseases.

The value is that I really understand a disease and the processes involved. The trade-off is that I didn't get from this class a detailed, intense, overwhelming class in cell bio.

Most people in this class are seniors, some graduating. So, by now we should know the range of basics. It is more beneficial to refine social skills \& many people could not use PowerPoint until this class.

I feel like I got a lot out of this class. Although I feel pretty fluent on my process, I didn't learn too much about the other groups' processes. Just getting ours down was work enough. If you wanted us to get more from the other groups, you may want to decrease on the workload.

\section{What will you remember about this class five years from now?}

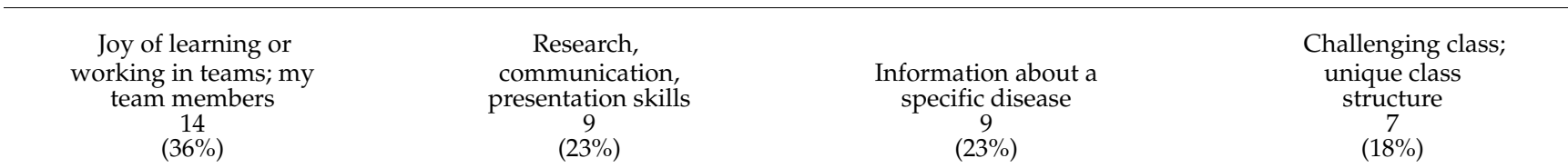

I will always remember the initial stress and grief of working in a team and the eventual improvement and ease of working with everyone after we communicated more on our problems.

The people, my group members, and the overall structure of the class; most important-how to make a poster.

It was very fun to talk in front of other people and explain like you are a scientist.

The stress that leads up to the final product and the accomplishment at seeing it done.

I learned a lot of molecular biology techniques that have already overlapped with other classes and readings.

The skills needed to interact in a team. 


\section{Now that the class is over, what do you think are advantages and disadvantages of learning and doing projects in teams?}

The advantages are that people can compensate and cover for fellow teammates. Also, teams can brainstorm for really creative ideas and sometimes a person can research part of the project that interests him/her the most. The disadvantages are that there might be conflicting working styles and personalities. Furthermore, one would have to be willing to compromise on ideas regarding papers, presentations, etc.

Teamwork forces people to work a little harder so you don't let your team members down. The disadvantage would be, some members may skate by on the work of the more motivated members.

Advantages-you learn more, cover more ground than you could by yourself; something may be uninteresting to one but interesting to another in your team.

Presentation \& how to write scientific paper was greate [sic] opportunity. Even the [sic] only one member of the group doesn't work seriously, all group member [sic] get worse.

Advantage: more people = more ideas and more knowledge; Disadvantage: hard to coordinate our schedules for meeting times.

It was a big weight off, since I wasn't responsible for everything. Also, I think the final outcomes were much more creative than I could have done myself.

I'm more apt to ask for and receive criticism of my own work in the context of a team. However, all projects take several times longer to complete. The projects, of course, are usually of better quality.

Advantages: Get more info \& do projects faster and better; Disadvantages: some people care more \& do a little more work \& the teacher can't see that. 